\title{
France: Submerged Prehistory on Atlantic and Mediterranean Coasts
}

\author{
Cyrille Billard, Marie-Yvane Daire and \\ Chloé Martin, with contributions by Yves Billaud, \\ Catherine Bizien-Jaglin, Antoine Chancerel, \\ Dominique Cliquet, Nathalie Fourment, \\ Henri Gandois, Briagell Huet, Marine Laforge, \\ Loïc Langouët, Luc Laporte, Jean-Marc Large, \\ Frédéric Leroy, Elías López-Romero, \\ Léopold Maurel, Jean-Laurent Monnier, \\ Pierre Régaldo, Anne Ropars, Pierre Stéphan, \\ and Luc Vallin
}

\begin{abstract}
The French coastline accounts for many submerged remains of prehistoric sites along all its coastlines. Undisturbed sites including intertidal deposits containing artefacts give a total of 180 find spots. Each geographical region has its own specific features: submerged peats and fish weirs along the Channel and Atlantic coasts, faunal assemblages from the Channel and the North Sea, underwater sea caves and karsts along parts of the Mediterranean coast and occupations dated to later prehistory on the Mediterranean and in the south-western coastal lagoons. Coastal archaeology successfully confirms the high potential and good preservation of submerged sites, particularly organic artefacts such as
\end{abstract}

wooden objects, features related to fishing and faunal assemblages. New types of sites and research issues have emerged over the past decade, particularly Palaeolithic sites, Neolithic axe deposits in association with megalithic complexes and fishing structures reflecting a widespread activity along the coasts of the Channel and the Atlantic Ocean. The implementation of a scientific programme relating to submerged sites is all the more urgent since offshore industrial projects are rapidly increasing along the French coasts.

\section{Keywords}

Megaliths · Fish weirs - Cosquer Cave ·

Middle Palaeolithic sites · Pleistocene fauna .

Karst caves $\cdot$ Intertidal archaeology
C. Billard $(\bowtie) \cdot$ D. Cliquet

DRAC-SRA Normandie, Caen, France

UMR 6566 Centre de Recherche en

Archéologie, Archéosciences, Histoire,

Caen, France

e-mail: cyrille.billard@culture.gouv.fr; dominique.cliquet@culture.gouv.fr
M.-Y. Daire

CNRS, UMR 6566 Centre de Recherche en

Archéologie, Archéosciences, Histoire,

Rennes, France

Association Manche Atlantique pour la Recherche Archéologique dans les Îles, Rennes, France e-mail: marie-yvane.daire@univ-rennes1.fr 


\subsection{Introduction}

The French coastline extends for $5834 \mathrm{~km}$ and faces four marine basins with highly varied coastal and offshore conditions: the southern edge of the North Sea, La Manche or the (English) Channel, the Atlantic and the Mediterranean. Extensive offshore areas of submerged landscape were exposed at the Last Glacial Maximum, especially in the north-west (Farr et al. 2017). These submerged landscapes are of particular interest because they were adjacent to some of the most important concentrations of Palaeolithic and Mesolithic sites in Europe, and their emergence and subsequent inundation are likely to have played an important role in changing pat-

\section{Martin}

CNRS, UMR 6566 Centre de Recherche en

Archéologie, Archéosciences, Histoire,

Rennes, France

Association Manche Atlantique pour la Recherche Archéologique dans les îles, Rennes, France

Centre Régional d'Archéologie d'Alet,

Rennes, France

\section{Y. Billaud · F. Leroy}

Département des Recherches Archéologiques

Subaquatiques, Marseille, France

Sous-Marines, Marseille, France

e-mail: yves.billaud@culture.gouv.fr;

frederic.leroy@culture.gouv.fr

C. Bizien-Jaglin

Centre Régional d'Archéologie d'Alet,

Rennes, France

A. Chancerel

Musée National de Préhistoire, Les Eyzies, France e-mail: antoine.chancerel@culture.gouv.fr

N. Fourment · L. Maurel · P. Régaldo

DRAC-SRA Grande Aquitaine, Bordeaux, France e-mail: nathalie.fourment@ culture.gouv.fr; leopold.maurel@culture.gouv.fr; pierre.regaldo@culture.gouv.fr

H. Gandois

UMR 6566 Centre de Recherche en Archéologie, Archéosciences, Histoire, Caen, France

UMR 8215, Université Paris 1, Panthéon, Sorbonne, Rennes, France

B. Huet

UMR 6566 Centre de Recherche en Archéologie, Archéosciences, Histoire, Caen, France terns of settlement and demography in France and between France and the adjacent regions of Britain and northern Spain (see Bailey et al., Chap. 10, this volume; Arias, Chap. 13, this volume). Little is presently known about the archaeology of deeper areas of this extensive submerged landscape apart from isolated materials, mostly animal bones, dredged up during offshore fishing and industrial activity. Systematic investigation of prehistoric remains is largely confined to shallower water and the intertidal zone.

Despite its variability in tidal range, climate and forms of coastal relief, France harbours many such remains of prehistoric sites inundated by sea-level rise (Fig. 12.1). Interest in this theme began in the nineteenth century with

\section{Laforge}

UMR 6566 Centre de Recherche en Archéologie, Archéosciences, Histoire, Caen, France

ÉVEHA, Vezin-Le-Coquet, Rennes, France e-mail: marine.laforge@eveha.fr

\section{Langouët}

Association Manche Atlantique pour la Recherche Archéologique dans les Îles, Rennes, France

Centre Régional d'Archéologie d'Alet, Rennes, France

L. Laporte $\cdot$ J.-L. Monnier

CNRS, UMR 6566 Centre de Recherche en

Archéologie, Archéosciences, Histoire,

Rennes, France

e-mail: luc.laporte@univ-rennes1.fr;

jean-laurent.monnier@univ-rennes1.fr

\section{J.-M. Large}

Groupe vendéen d'études préhistoriques, membre associé UMR 6566 Centre de Recherche en Archéologie, Archéosciences, Histoire,

Rennes, France

E. López-Romero

Université de Bordeaux, Bordeaux, France e-mail: elias.lopez-romero@u-bordeaux-montaigne.fr

\section{A. Ropars}

DRAC-SRA Normandie, Caen, France

e-mail: anne.ropars@culture.gouv.fr

P. Stéphan

UMR 6554 LETG-Brest Géomer CNRS - Institut

Universitaire Européen de la Mer, Brest, France

L. Vallin

DRAC-SRA Hauts-de-France, Lille, France

e-mail: luc.vallin@culture.gouv.fr 


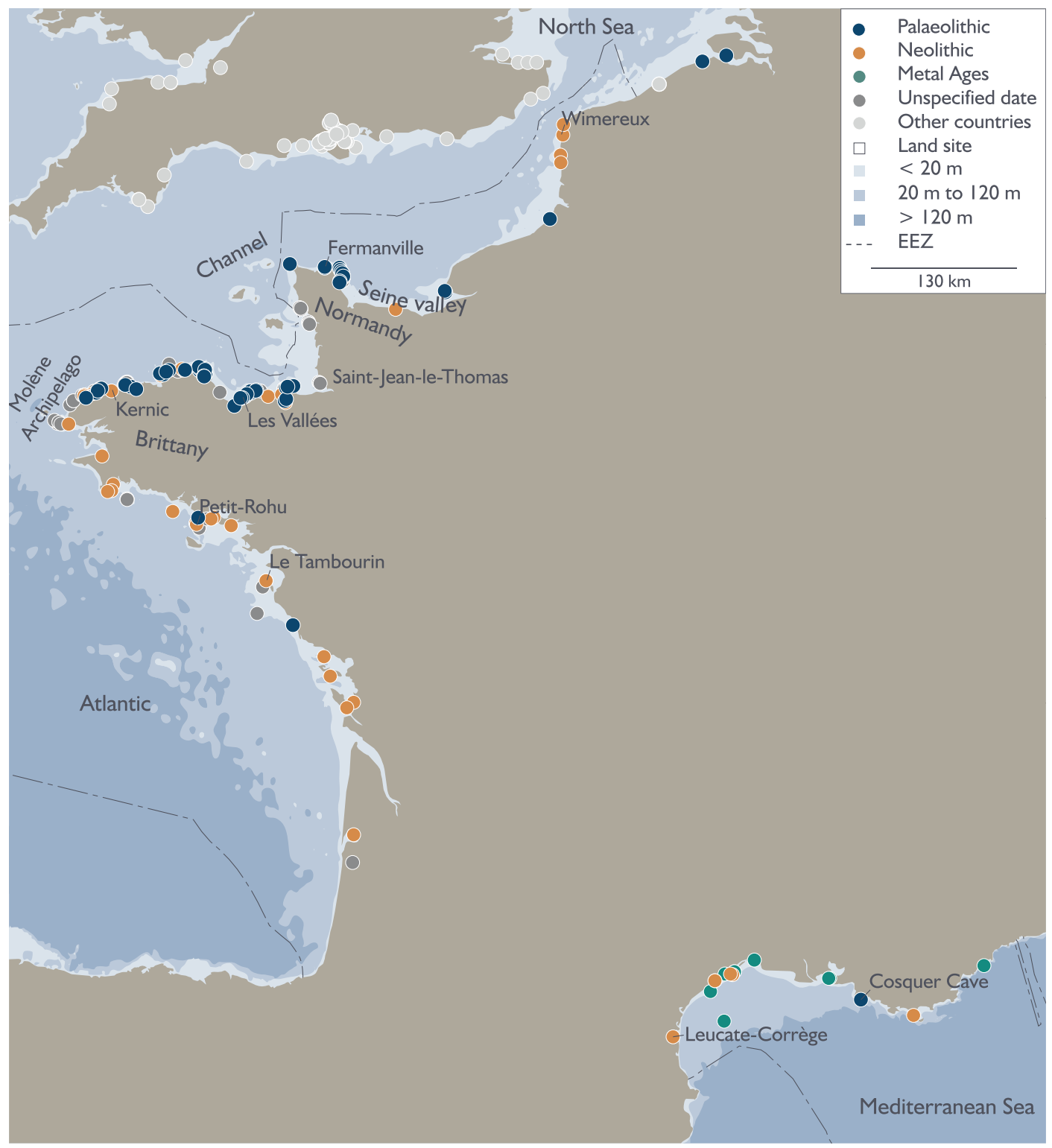

Fig. 12.1 Map of prehistoric submerged sites off the French coasts. Site information from the SPLASHCOS Viewer http://splashcos-viewer.eu. Drawing by Moritz Mennenga

observations of megalithic monuments below high-tide level. Here, we focus on sites with undisturbed material earlier than 5500 cal BP, including deposits in the intertidal zone that contain artefacts and fauna, Bronze Age sites and some multiperiod sites that have been submerged. Sites on the landward side of the shoreline that are in the process of being eroded by wave action are intentionally excluded.
For the presentation of the sites, we divide these into two main groups, the first associated with Palaeolithic sites and Pleistocene faunas and the second with Neolithic and later sites and monuments. Within each group, we present the material in broadly geographical order, working from north to south along the Channel and Atlantic coasts and from west to east along the Mediterranean. 


\subsection{Types of Submerged Sites}

Currently, there are 180 known submerged prehistoric sites (Table 12.1). These are widely distributed along the coastline, but the regions of western France are best represented, especially from the mouth of the Charente to the Cotentin (Figs. 12.2, 12.3, 12.4 and 12.5). Each geographical area offers its own specific features: submerged peats and fish weirs along the Channel and the Atlantic coasts, faunal assemblages along the Channel and the North Sea, occupations dated to later prehistory in the coastal lagoons of the south-west and the Mediterranean and submarine caves and karsts along the Mediterranean (Fig. 12.6).

The majority of the sites (82) are of indeterminate prehistoric age. Of those that can be more closely dated, Palaeolithic sites (42) and Neolithic sites (40) are the main categories with a significant number from the Middle Palaeolithic period (16). As for the different categories of sites, stone fish weirs of indeterminate date (57) predominate, with just 3 wooden examples of Late Neolithic or Early Bronze Age date, followed by 26 submerged or partially submerged megalithic monuments of Neolithic age. The remainder are cultural layers of uncertain function.

\subsection{Sea-Level Variations and Palaeogeographical Changes}

There is now a considerable body of data about the pattern and chronology of late Pleistocene sea-level change on the French coastline and its relationship to global sea-level changes, based on evidence from raised beaches, offshore sediments, submerged peats and the sedimentary infills of palaeo-valleys, especially from Normandy and Brittany in the north-west and the Golfe de Gascogne in the south-west (Coutard 2003; Toucanne 2008; Laforge 2012; Sorrel et al. 2012; Stéphan and Goslin 2014; Stéphan et al. 2015).
As elsewhere, the general pattern of change since the Last Glacial Maximum is a eustatic sea-level rise from a maximum depth of $\mathrm{c}$. $-125 \mathrm{~m}$ at c. $17,000 \mathrm{cal} \mathrm{BP}$ to $-5 \mathrm{~m}$ at c. $7000 \mathrm{cal}$ $\mathrm{BP}$ with an average rate of sea-level rise of $12 \mathrm{~mm} /$ year during this period (Lambeck et al. 2002, 2014; Harff et al. 2017; Bailey et al., Chap. 1, this volume). A detailed analysis of SLIPs (Sea-Level Index Points) confirms this general trend along the French coastline (Figs. 12.7 and 12.8; Stéphan 2012; Stéphan and Goslin 2014; Goslin et al. 2015; Stéphan et al. 2015) and supplies additional details that demonstrate the following:

- Sea-level rise slowed down significantly after 7000 years ago, with a slow and steady rise since then towards the present sea-level at a rate of $\leq 1 \mathrm{~mm} /$ year.

- Regional variations in RSL (relative sea level) during the Holocene are the result of variations in glacio-hydro-isostatic adjustment of the Earth's crust.

- There is no evidence for a Holocene sea level higher than the present or for alternations of transgressive and regressive phases. Earlier interpretations to this effect (e.g., Morzadec-Kerfourn 1974; Ters 1986; Stéphan 2011) failed to take into account isostatic adjustments or changes in shoreline sedimentation and geomorphology.

The Molène archipelago exemplifies the impact of sea-level rise in terms of coastal palaeogeographical changes (Fig. 12.9). These islands constitute the emerged part of a large shallow-water rocky platform that was attached to the mainland at the Last Glacial Maximum. With the gradual rise of sea level, this was transformed at first into a single, large island and then into a variety of smaller islands and islets, removing from view almost of traces of human activity on this submerged landscape apart from a number of stone fish traps (Dréano et al. 2013; Gandois et al. 2013a, b; Stéphan et al. 2013; Pailler et al. 2014). 


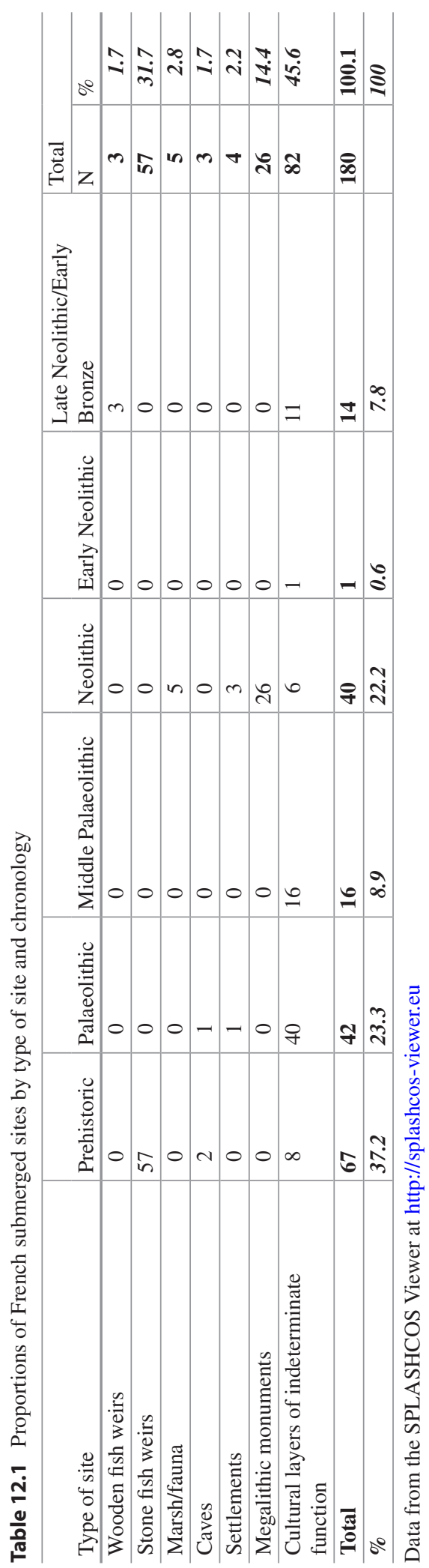


Fig. 12.2 Map of prehistoric submerged sites off the Channel and North Sea coasts of France. Site information from the SPLASHCOS Viewer http://splashcosviewer.eu. Drawing by Moritz Mennenga

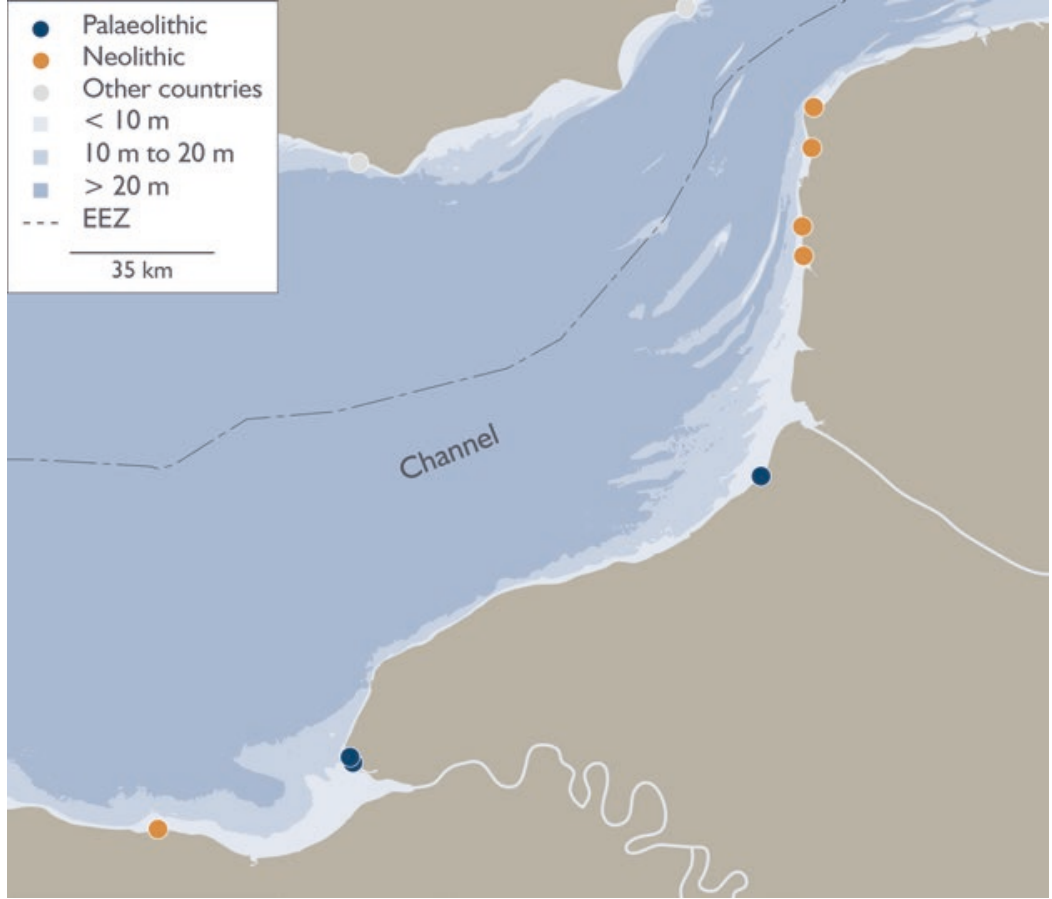

Fig. 12.3 Map of prehistoric submerged sites off the Cotentin coast and the NormanBreton Gulf. Site information from the SPLASHCOS Viewer http://splashcos-viewer. eu. Drawing by Moritz Mennenga

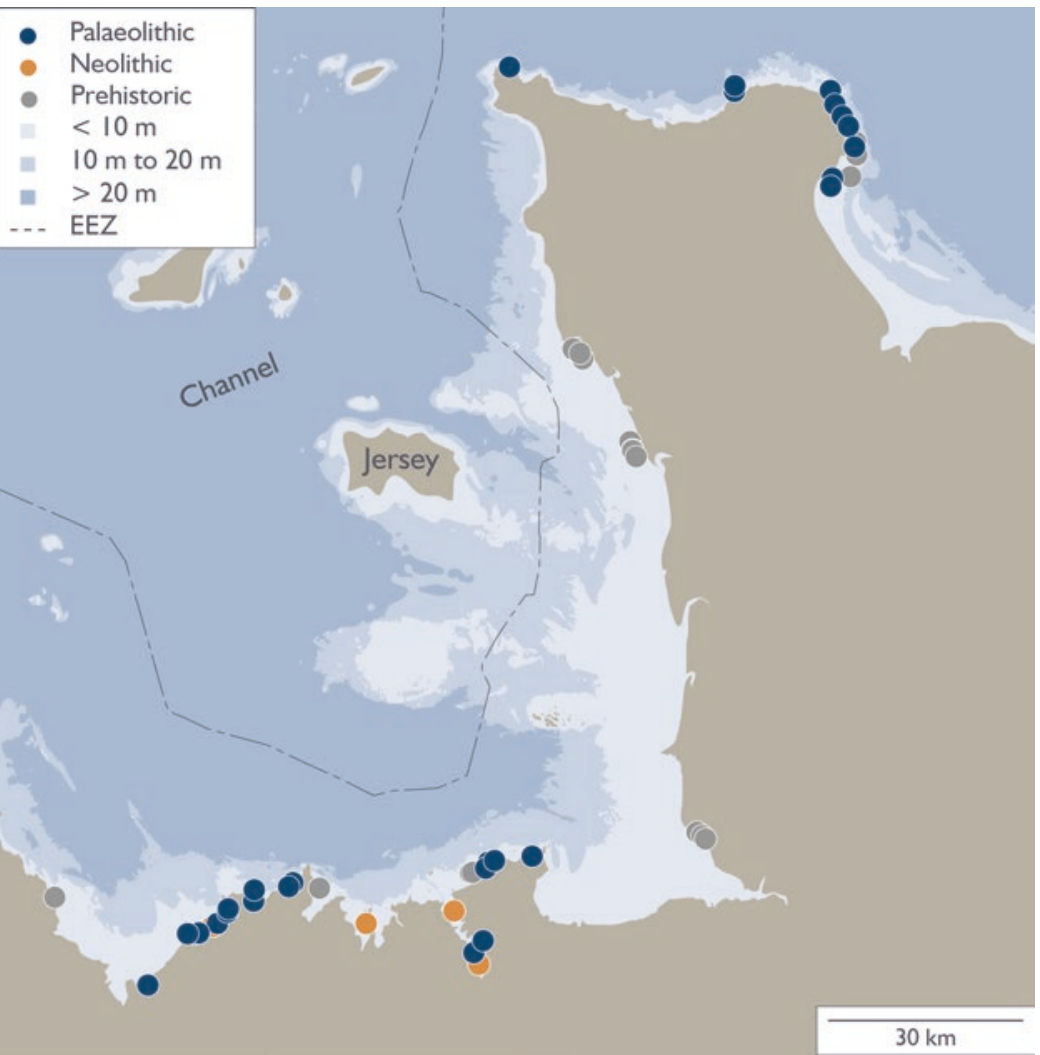




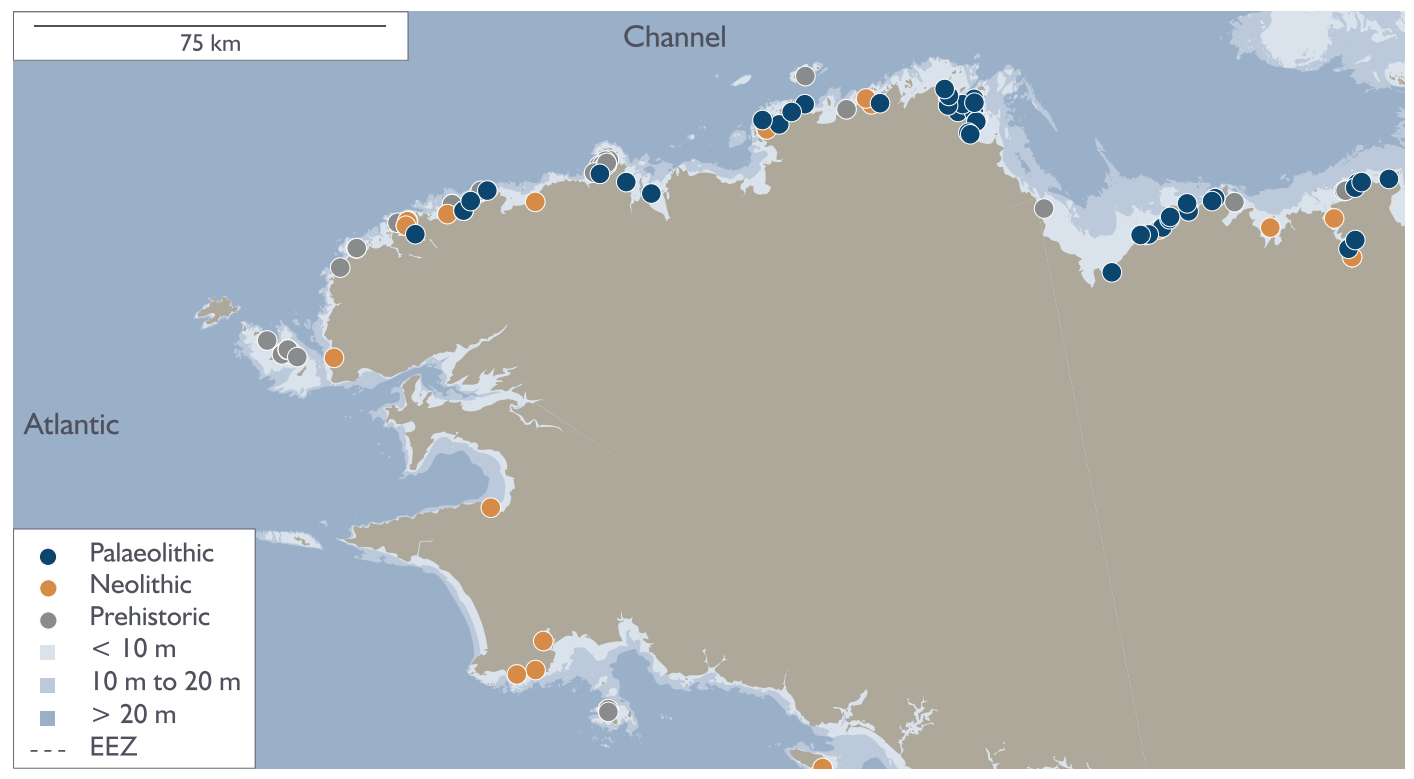

Fig. 12.4 Map of prehistoric submerged sites off the Brittany coast. Site information from the SPLASHCOS Viewer http://splashcos-viewer.eu. Drawing by Moritz Mennenga

\subsection{Sites with Palaeolithic Artefacts and Pleistocene Fauna}

\subsubsection{The Northern Armorican Massif (Golfe Normand-Breton)}

There are numerous Lower and Middle Palaeolithic finds along the shorelines of this region associated with Pleistocene deposits, and Middle Palaeolithic sites are especially common along the north coast of Brittany and Cotentin (Fig. 12.3; Coutard 2003; Coutard and Cliquet 2005; Monnier 2006; Lefort et al. 2011; Monnier et al. 2011). All are associated with Pleistocene deposits of various types, including raised beaches, loess and periglacial deposits, and many of the artefacts are made on flint derived from Cretaceous formations that are now submerged. The beach along this coastline is backed by a marine cliff which has been eroded by marine action and reveals stratified Pleistocene deposits in section. Some of these sites are associated with earlier periods of high sea level, particularly MIS 5e (Eemian), others with the Last Glacial Period (MIS 4 and 3). These deposits are geologically in situ, but it is sometimes difficult to distinguish those that are at the base of the cliff from those that are being exposed in the intertidal zone by erosion of the overlying beach deposits (Monnier et al. 2011). We present below examples of the latter type, which clearly belong to a land surface that was subsequently inundated by sea-level rise.

There are several dozens of sites that are geologically in situ in the intertidal zone (Giot et al. 1973; Monnier 1986; Huet 2002, 2006; Laforge 2012), notably the site of Les Gastines (Ille-etVilaine), which has undergone a systematic excavation (Monnier 1988). Mention should also be made of some famous sites excavated at the foot of cliffs or near ancient submarine caves and associated with now-submerged landscapes, notably Piégu (Côtes-d'Armor), La Cotte de Saint-Brelade in Jersey (see also Bailey et al., Chap. 10, this volume) Mont-Dol (Ille-etVilaine), Karreg-ar-Yellan (Côtes-d'Armor) and Saint-Germain-des-Vaux/Port-Racine (Manche). 


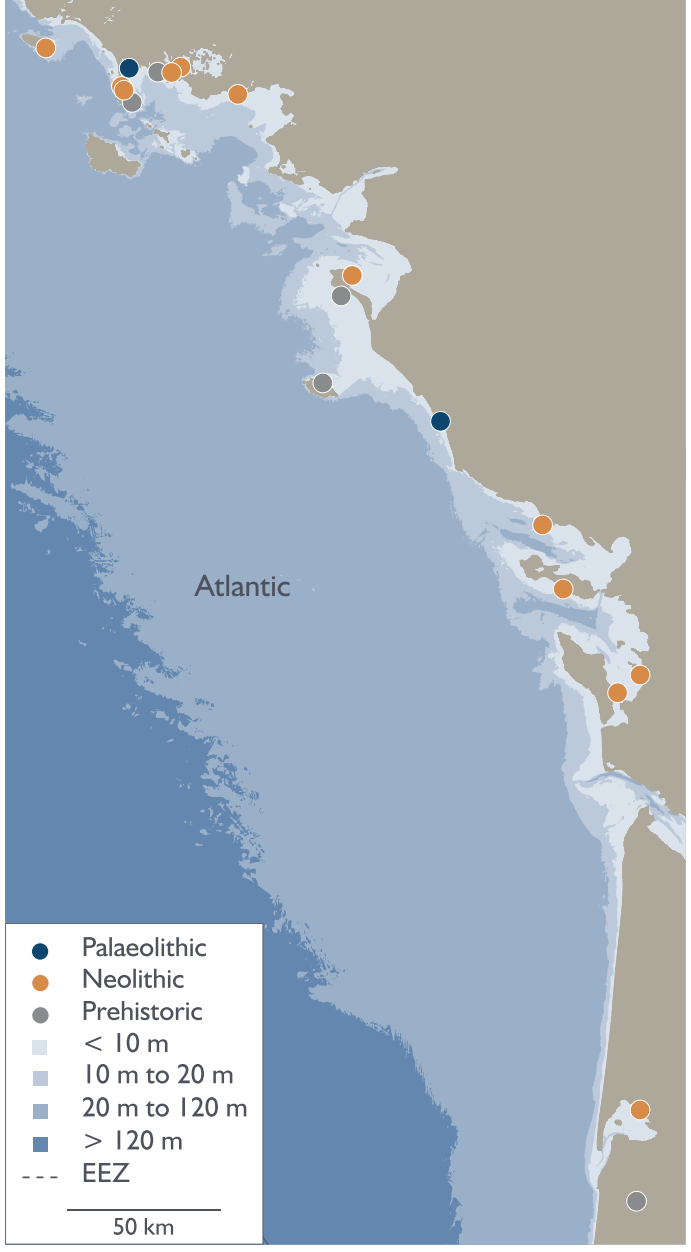

Fig. 12.5 Map of prehistoric submerged sites off the Aquitaine coast. Site information from the SPLASHCOS Viewer http://splashcos-viewer.eu. Drawing by Moritz Mennenga
In Gatteville-Le-Phare (Manche), at Anse du Figard, flint implements are associated with a marine deposit attributed to the Eemian (Michel et al. 1982). The lithics were made from Cenomanian flint coming from a barrier beach and are characterised by a predominantly Levallois debitage with notches, denticulates, side scrapers and some pebble tools. In the tidal creek of Portbail (Manche), a Middle Palaeolithic flint industry is associated with a hard sand-clay level and underlying gravels affected by ice action (Laisné and Vilgrain 2008).

Chausey, offshore from Granville (Manche), is an archipelago of 52 islands and 365 islets. With a tidal range of $14 \mathrm{~m}$, extensive areas of the intertidal zone and some of the islets become exposed at low tide, and several shore areas have yielded Middle Palaeolithic tools (Pruvost 2006).

In the Normandy region, some other Palaeolithic industries have been reported, notably at Agon-Coutainville (Manche), Asnelles, Meuvaines, Ver-sur-Mer and between Villerssur-Mer and Houlgate (Calvados). Further south, in the Charente, particularly at the mouth of the Seudre and Charente Rivers, there are many submerged remains, the oldest dating back to the Middle Palaeolithic, some near ancient terraces (Fridman 1957), others in the Marennes-Oléron basin (Maufras 1874; Hinout and Rolland 1960) and around the Islands of Aix and Madame (Facon 1967; Néraudeau and Bourgeois 1994).

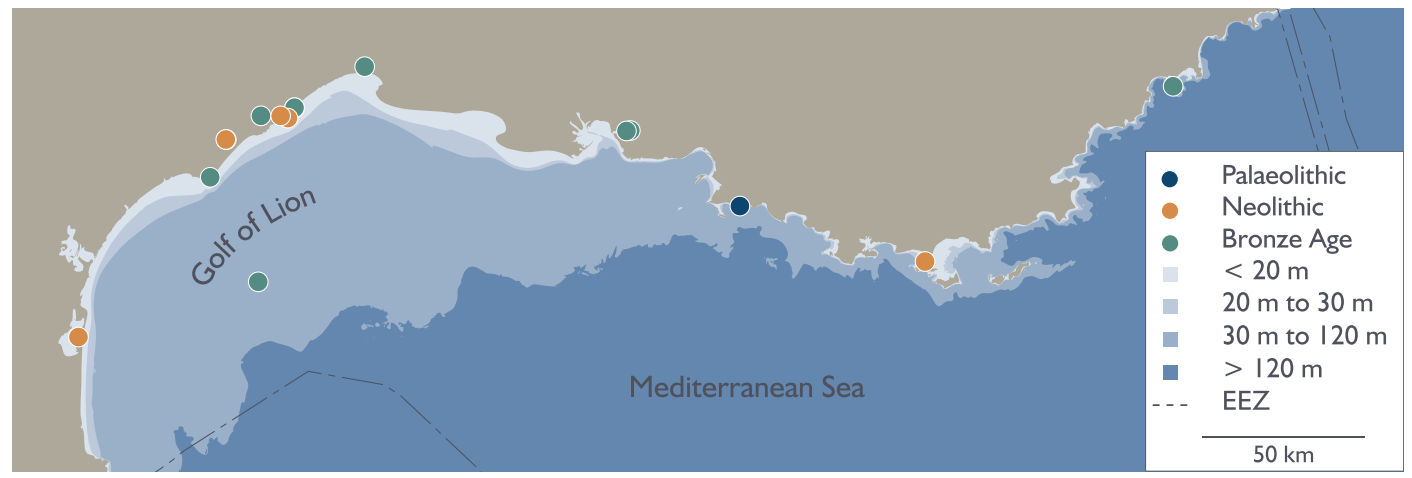

Fig. 12.6 Map of prehistoric submerged sites off the Mediterranean coast of France. Site information from the SPLASHCOS Viewer http://splashcos-viewer.eu. Drawing by Moritz Mennenga 


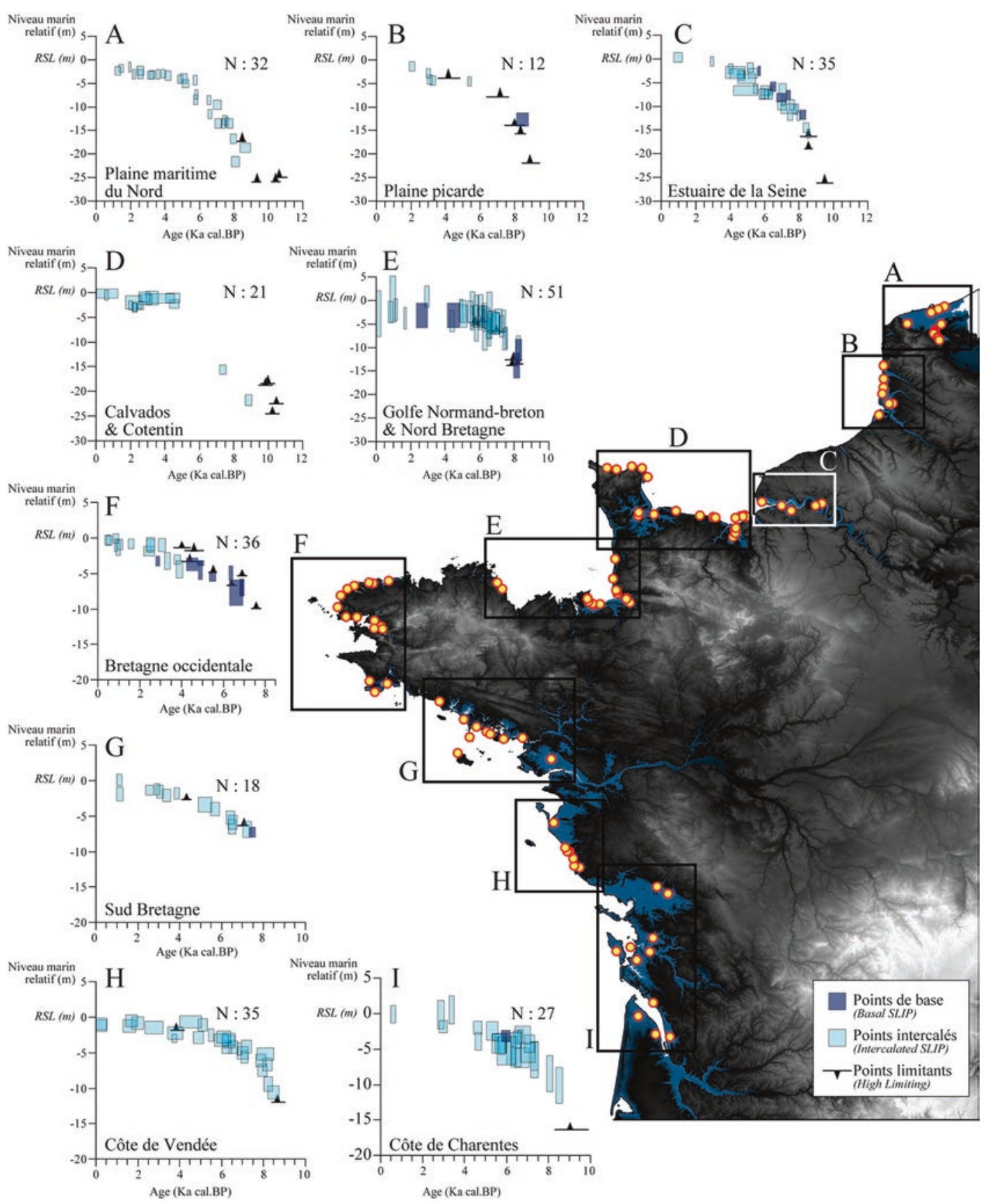

Fig. 12.7 Sea-level variations along French Channel-Atlantic coasts during the Holocene. After Stéphan and Goslin (2014) 


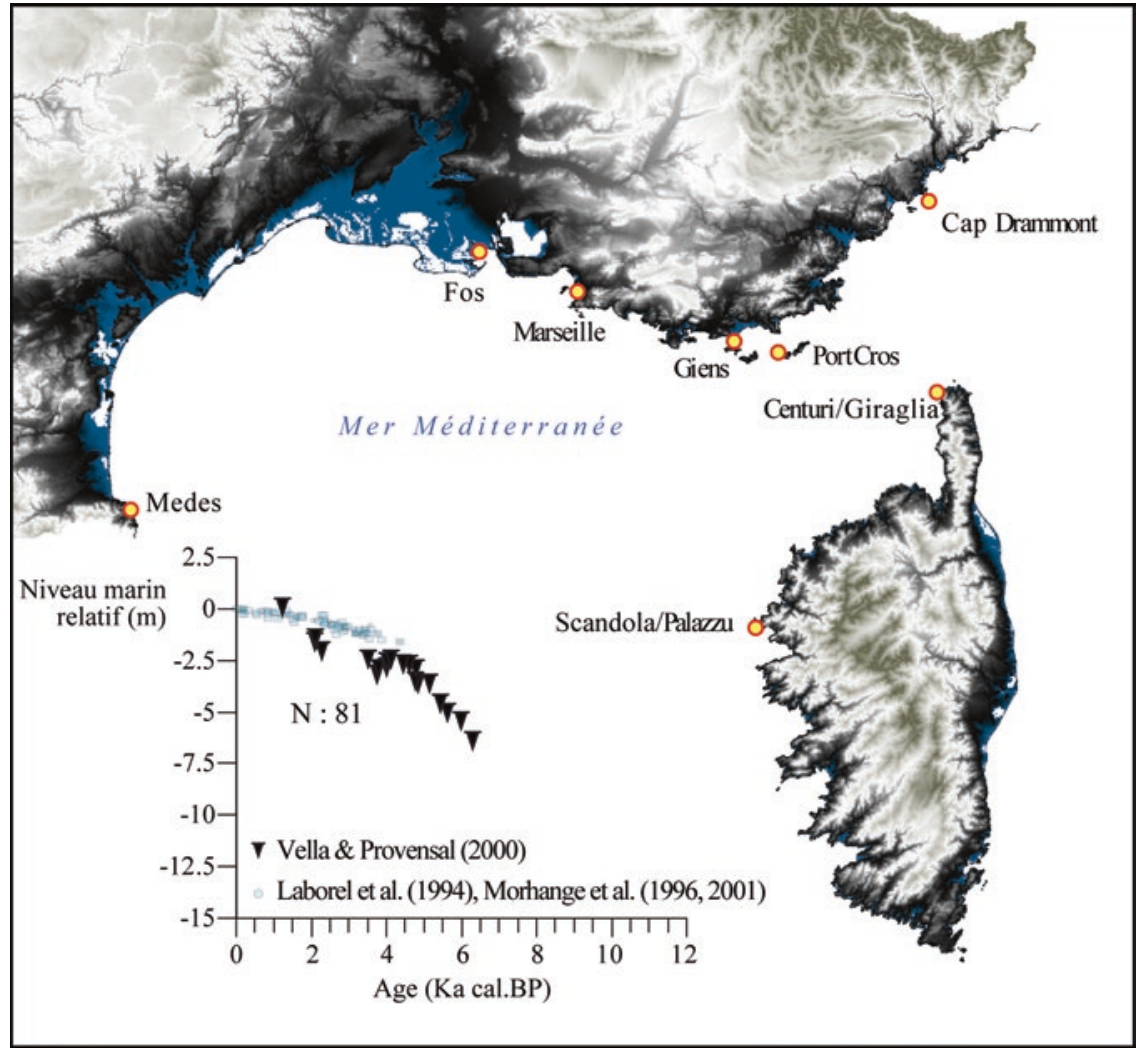

Fig. 12.8 Sea-level variations along the French Mediterranean coast during the Holocene. After Stéphan and Goslin (2014)

\subsubsection{Pléneuf-Val-André'Les Vallées' (Côtes-d'Armor, France): A Neanderthal Workshop and Butchery Site}

The Palaeolithic site of Les Vallées is an open-air site located in the intertidal zone today (Fig. 12.10). Originally, it was located near a small stream at a time when sea level was $60 \mathrm{~m}$ bpsl (below present sea level) and the coastline was approximately $60 \mathrm{~km}$ further out (Laforge 2012). On geological grounds, the archaeological material is associated with a cold period earlier than the Last Interglacial, most likely the Saalian glaciation (MIS 6), confirmed by ESR and U/Th dates on bone giving an average age of $164 \pm 13 \mathrm{ka}$ (Bahain et al. 2012).

The material indicates a workshop linked with butchery activities and yielded some 2500 artefacts made on flint and quartz with numerous fau- nal remains dominated by horse, bison or aurochs and deer (Huet 2010). The artefacts were made by a recurrent knapping technique, with side scrapers of various types, Mousterian points and denticulates. Mammoth remains were discovered at this site at the beginning of the last century.

\subsubsection{Fermanville/Biéroc - La Mondrée (Manche-France)}

The site of La Mondrée in Fermanville lies at a depth of about $20 \mathrm{~m}$ bpsl and was first investigated during the 1970s, when it yielded an abundant Middle Palaeolithic assemblage of c. 2500 worked pieces (Fig. 12.11; Scuvée and Vérague 1988), with subsequent recovery of an equine tooth and two other bone fragments, one probably from an aurochs. New investigations from 2000 to 2002 by diver survey and again in 2010 were 


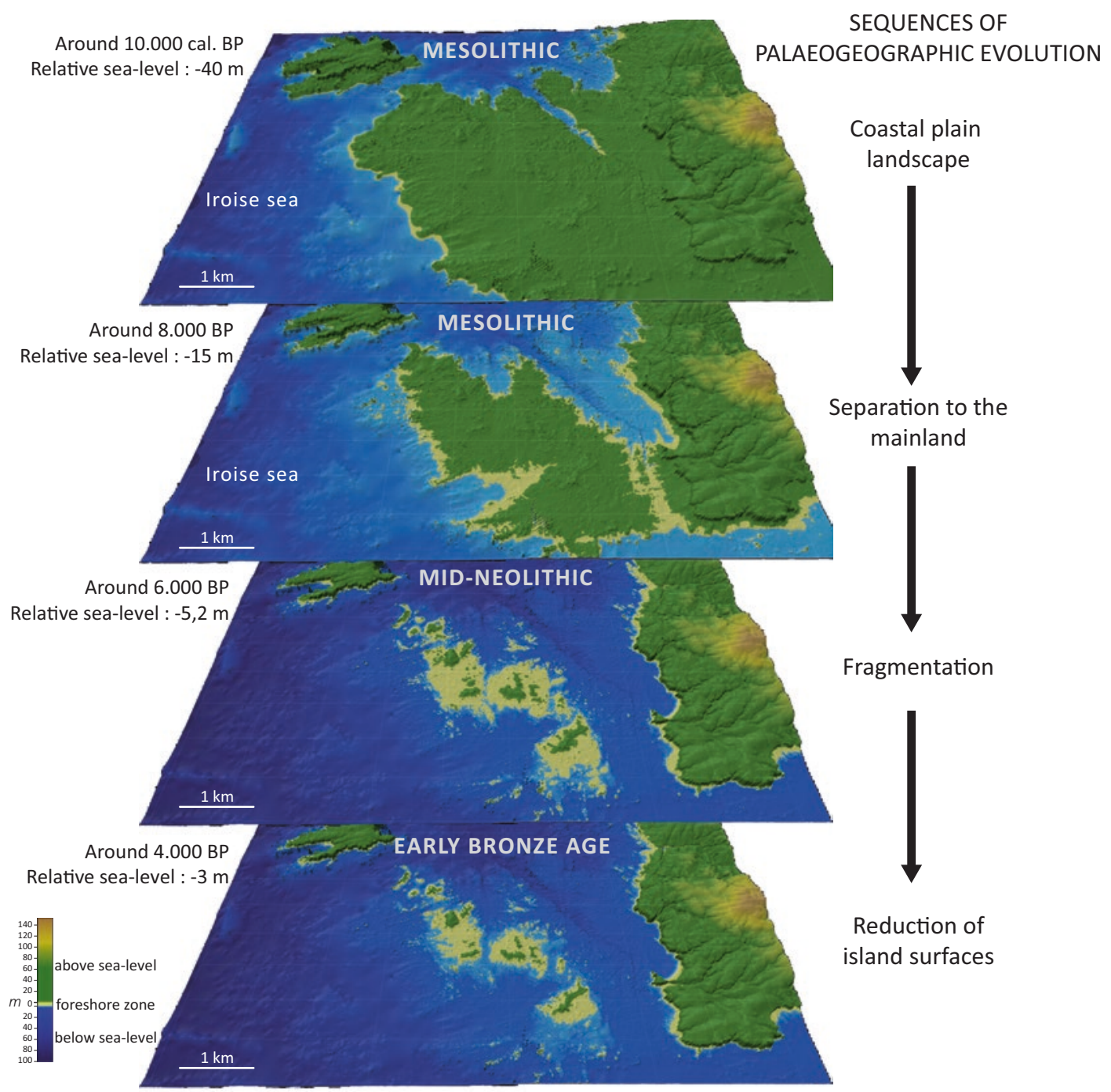

Fig. 12.9 Evolution of the Molène archipelago. Compiled by Pierre Stéphan

able to locate the original site, to examine the geomorphology of the cliff below which the site is found and to take core and bulk samples for stratigraphic, sedimentological, palynological and geochronological (OSL) analysis (Cliquet et al. 2011).

The 2002 survey revealed at least two occupation levels in situ. Pollen data indicate a date of MIS 5a, and OSL dating produced consistent results of c. $70 \mathrm{ka}$, corresponding to the boundary between MIS 5 and MIS 4 (Mercier et al. 2013). The stone assemblage is a Mousterian industry with scrapers and notched pieces; bovid and deer bones were also recovered and evidence of knapping areas and hearths (Coutard and Cliquet 2005). At the time of its occupation, the site was situated at the foot of a cliff looking out over a narrow coastal plain at the mouth of a small valley that gives access to an extensive plateau in the hinterland. The shoreline was perhaps no more than a few kilometres. This location would have provided shelter, large nodules of Cretaceous flint exposed during periods when sea level was lower than present and easy access to animal herds and to marine resources at the shore edge. 


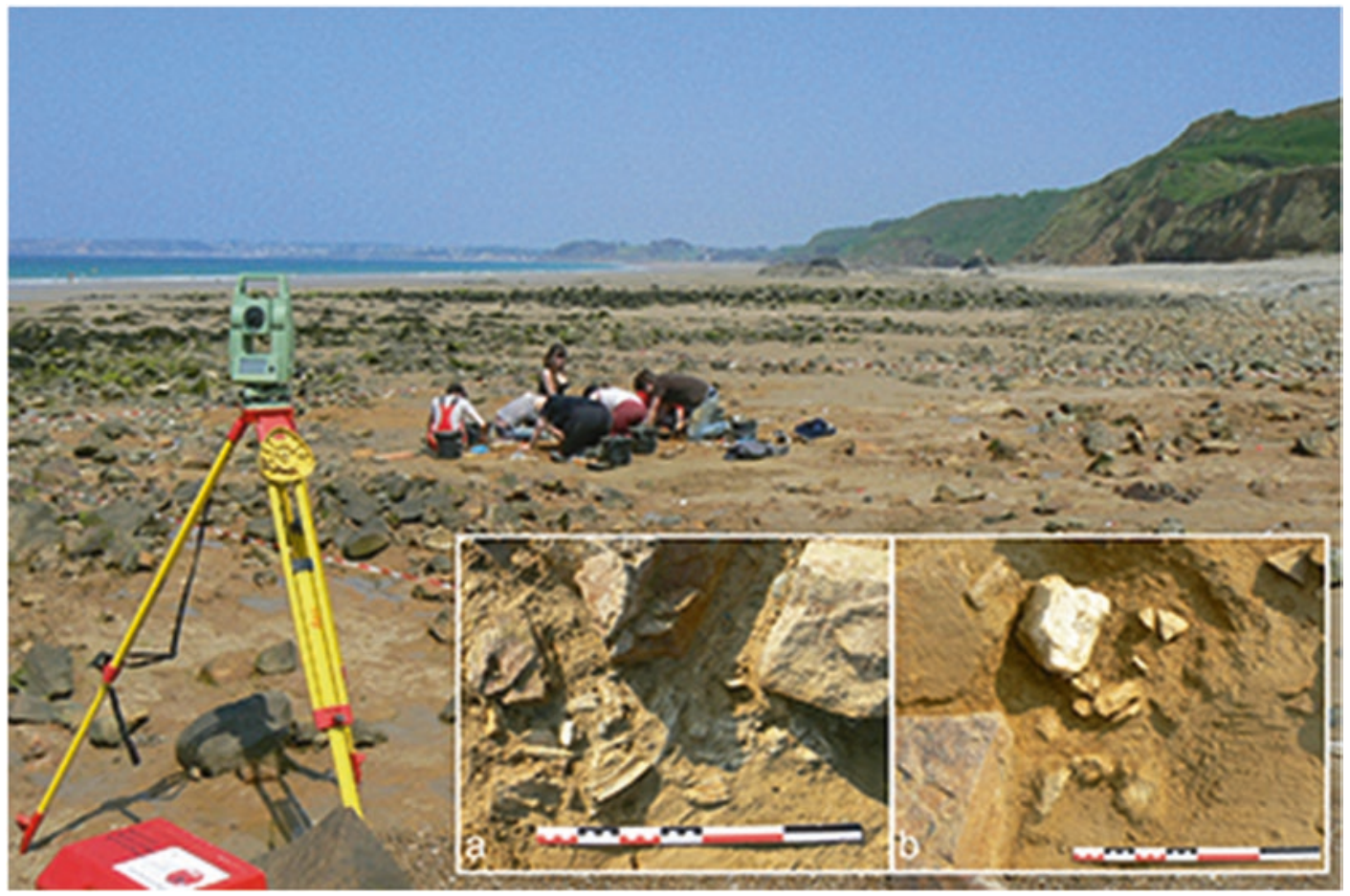

Fig. 12.10 The Middle Palaeolithic site of Les Vallées during excavation: (a) faunal remains and quartz flakes; (b) quartz cores and flakes. Photos by Briagell Huet

\subsubsection{North Sea, Channel and Atlantic Finds}

Since the middle of the nineteenth century, geologists have retrieved mammal bones from the bed of the North Sea. Trawler fishing in the Pas de Calais Strait has produced many bones, of which only the more spectacular have been reported such as mammoth teeth and tusks and bovid bones. Similar finds have been reported offshore of the Boulogne coast (Sauvage 1899) and from the Channel and Atlantic coasts.

The beaches of Le Havre are famous for their large Palaeolithic assemblages associated with fauna (Babeau 1906; Romain 1915). At $-2 \mathrm{~m}$ ODN (Ordnance Datum Newlyn; equivalent to mean tide level), the flint industry of the Station Romain includes bifaces and flakes linked to the MIS 7 interglacial. A rich fauna testifies to temperate environments (wild boar, roe deer, straight- tusked elephant [Palaeoloxodon antiquus]) and glacial environments (horse, mammoth, bison, reindeer).

There are numerous finds of Pleistocene fauna off the Normandy coast, particularly along the edges of the Seine palaeo-valley (Auguste, forthcoming). Mammoth remains (Mammuthus primigenius) have been found offshore of Barfleur (Manche) at a depth of $30 \mathrm{~m}$ (unpublished); at Courseulles-sur-Mer, Graye-sur-Mer, Luc-surMer, Port-en-Bessin and Villers-sur-Mer (Calvados); and at Cauville-sur-Mer, Saint-Jouin and Saint-Valéry-en-Caux (Seine-Maritime), the latter at a depth of 20 fathoms (Mercier 1934). Offshore of Barfleur, a horse tooth has been trawled at a depth of $20 \mathrm{~m}$ (unpublished). At Saint-Aubin-sur-Mer, on the Câtel beach (Calvados), mammoth and rhinoceros bones have been reported. At Saint-Côme-de-Fresné/Asnelles Belle-Plage (Calvados), the Eemian beach is cov- 


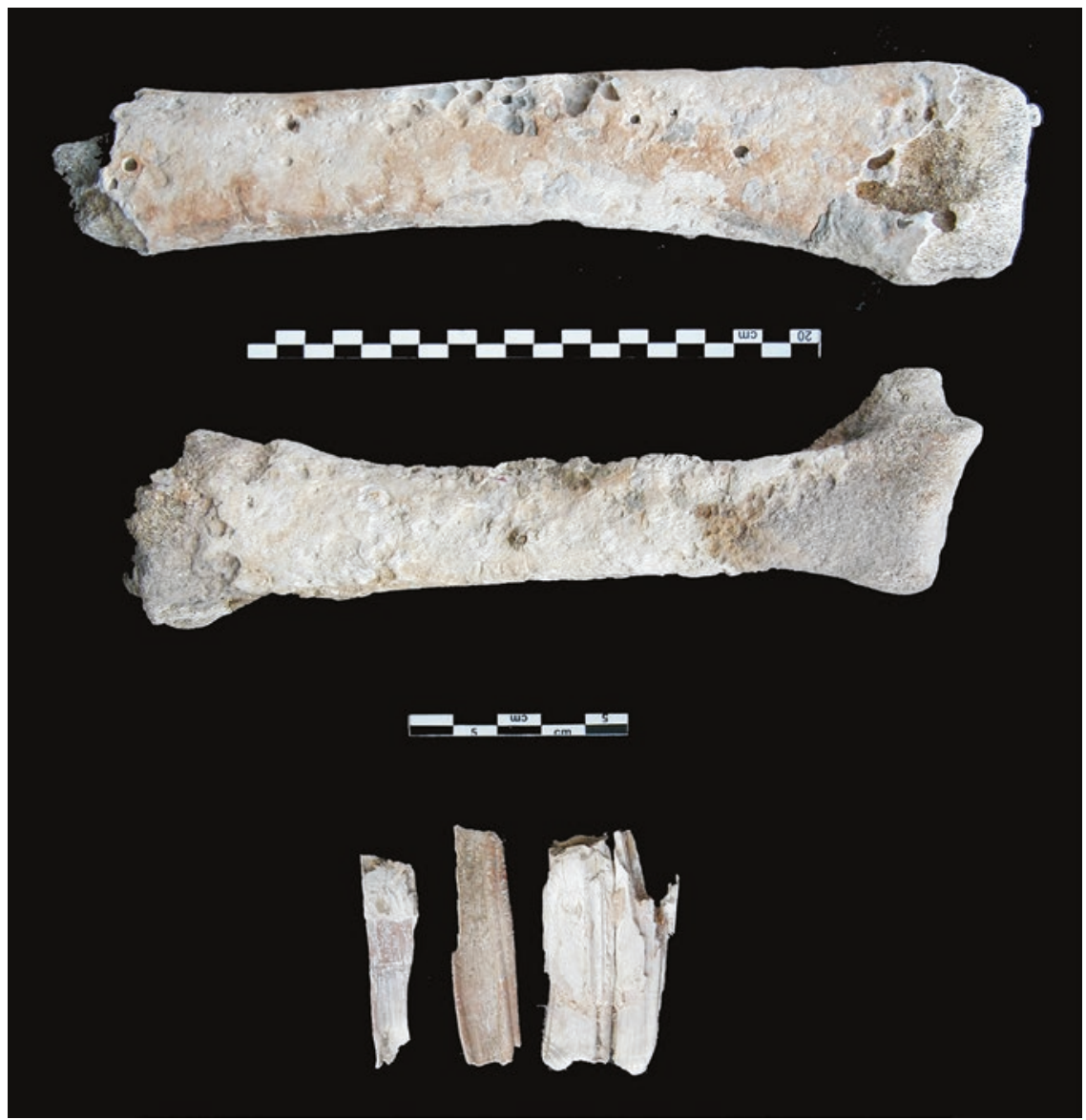

Fig. 12.11 The Fermanville La Mondrée site. Bones of aurochs (top) and deer (middle) picked up from the eroding surface of the site and fragments of an equid tooth (bottom) found in situ. Their deteriorated surfaces are due to biological decomposition. Photo by Dominique Cliquet

ered by peat and green clay of glacial age, in which faunal remains have been recovered as well as some flint tools (Guillaume 1935, 1952).

On the beaches of Brétignolles-sur-Mer (Vendée) particularly at Le Lac and Le Marais Girard, Elephas antiquus remains were found beneath a peat deposit lying on an Eemian conglomerate, apparently associated with some small pebble tools (Fig. 12.12; Labrude et al. 2000; Pouit and Viaud 2002). Full details have not been published, apart from a pollen analysis (Bernard and Visset 1992), which suggests an interglacial age, most probably MIS $5 \mathrm{e}$ (Eemian).

\subsubsection{Ault-Onival (Somme)}

The site of the Ault-Onival beach, on the south shoreline of the Somme estuary, was discovered at the beginning of the twentieth century, and more recently an important assemblage of flint cores, Levallois flakes and proboscidian bones was collected from low in the intertidal zone (Fig. 12.13; Agache 1968; Auguste, 2009; Antoine et al. 2011). The site is dated to the early Pleniglacial or the beginning of the middle Pleniglacial (MIS 4 or the MIS 3-4 transition), based on sedimentary features and an ESR/Uth date $(55 \pm 10 \mathrm{ka})$ on a horse tooth, and this is 


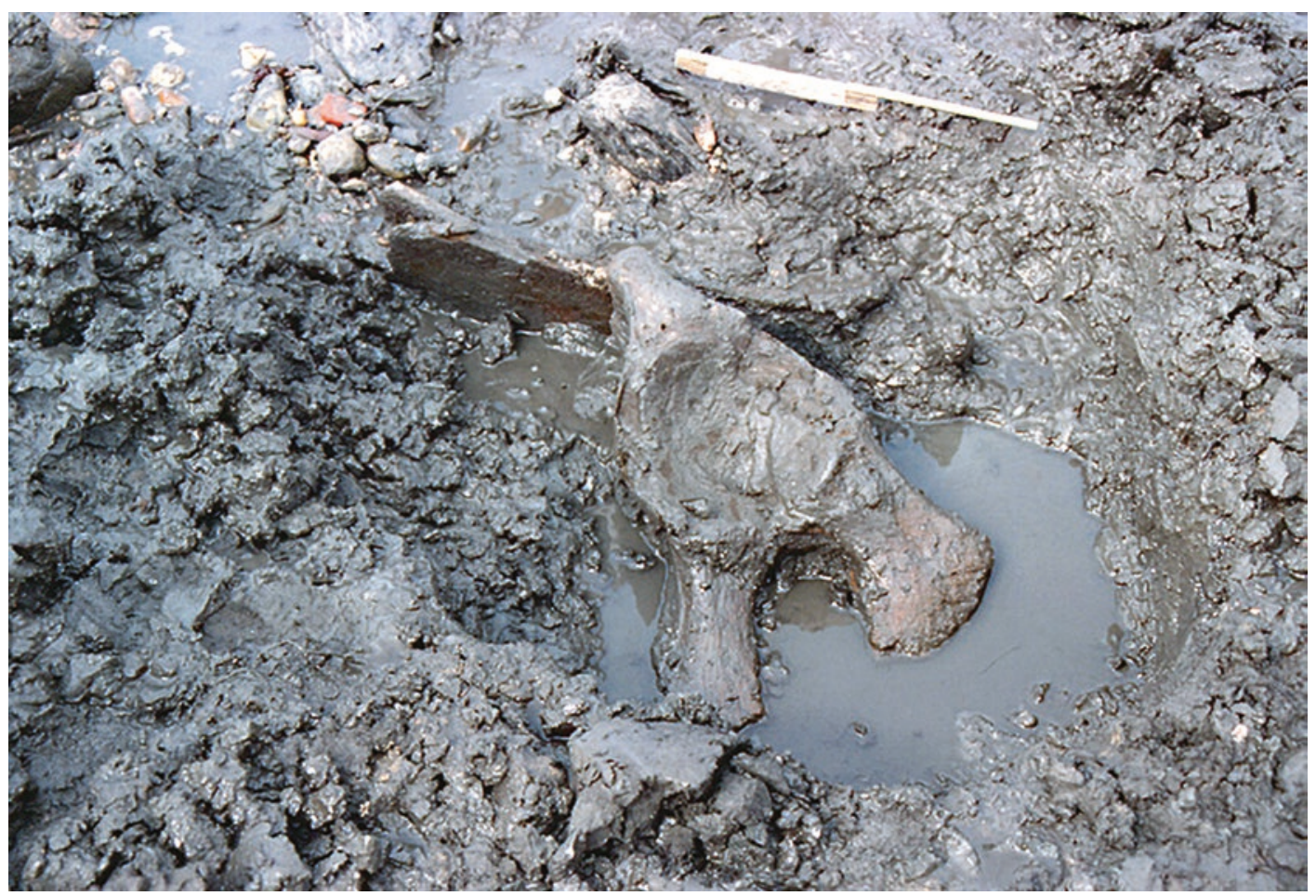

Fig. 12.12 La Parée beach in Brétignolles-sur-Mer (Vendée): Elephas antiquus remains in situ

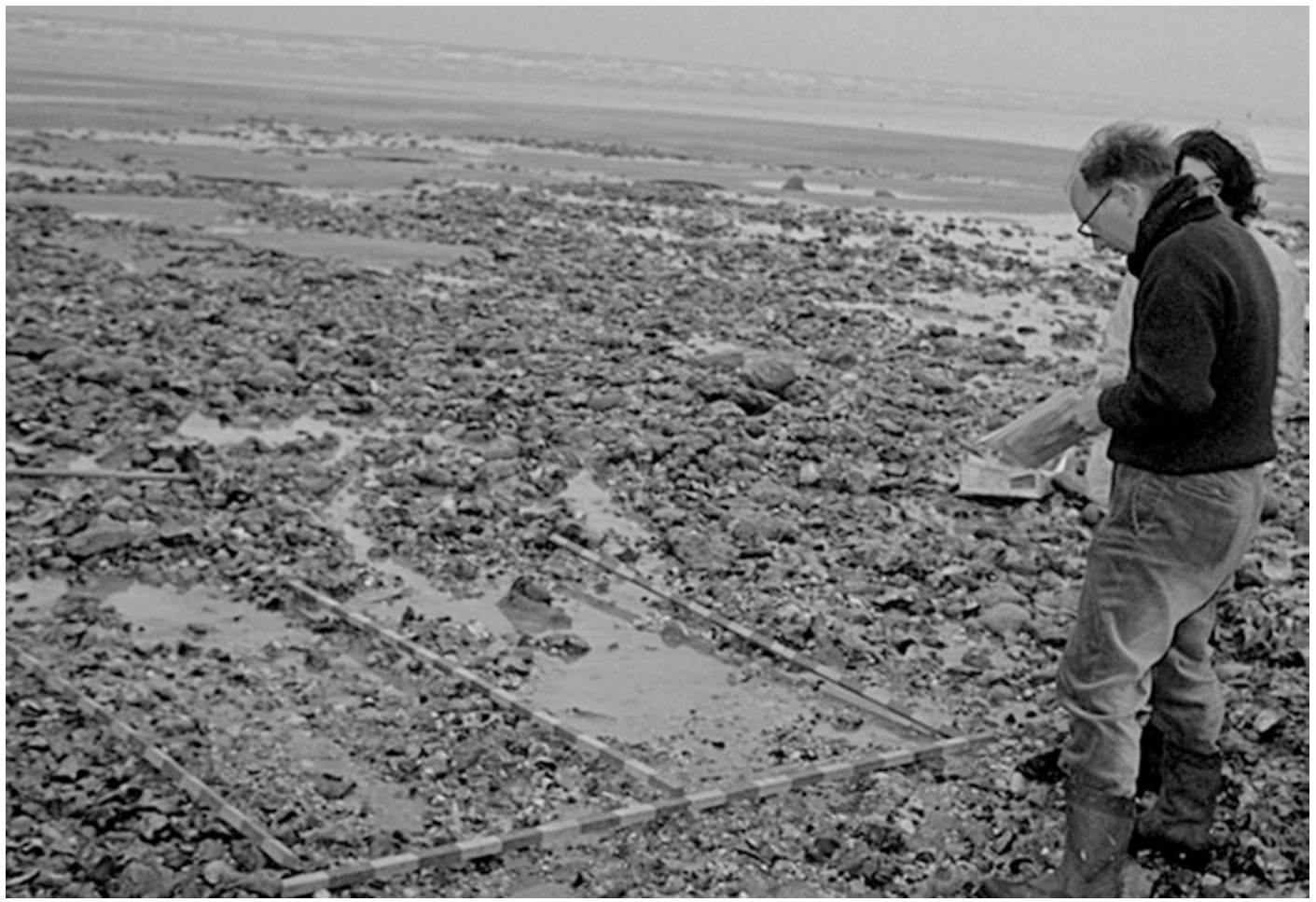

Fig. 12.13 Surveys by R. Agache on the Middle Palaeolithic site of Ault-Onival (Somme). Photo by DRAC Hauts de France-SRA 
consistent with the palaeontological data, mainly horse and Mammuthus primigenius (Auguste 2009; Antoine et al. 2011). The technological features of the industry and the position of the site indicate flint knapping activities near a source of raw material (Perpère 1986, 1999). The sedimentary origin of the deposit, as well as its situation under an ancient sea cliff created by coastal erosion, offers parallels with the section of the Sangatte fossil cliff, where dates of MIS 7 demonstrate that the Strait of Dover was open as a sea channel by that time (Antoine 1989; Balescu et al. 1992).

\subsubsection{South-West France}

No Pleistocene or Palaeolithic finds have been recovered along the coast of Aquitaine, but recent palaeoenvironmental research and archaeological survey in the hinterland raise questions about the environments available on the now-submerged coastal shelf. In the Landes triangle of the Aquitaine region of SW France, there existed an arid 'desert' during the Last Glacial Maximum (MIS 2), where coversands extended over a large area of low relief in the hinterland, exposed to winds and with little surface water, creating an inhospitable environment for human settlement, and a cultural barrier between the Pyrenees and Cantabria to the south and the Charente and the Périgord to the east and the north (Bertran et al. 2013). New studies of lithic technology and raw materials suggest that, despite this barrier, circulation of materials and movements of people persisted between the adjacent regions and that this may have taken place along the coastline of the submerged shelf, which extends for $50-100 \mathrm{~km}$ offshore from the present coastline. This hypothesis highlights the potential human significance of the submerged shelf and the need for offshore palaeoenvironmental studies, and ultimately the search for archaeological remains, to further explore this potential.

\subsubsection{The Mediterranean Coastal Karst}

The French Mediterranean coastline includes the following karstic massifs, from west to east (Fig. 12.6; Billaud 2017):

- Perpignan to Narbonne: the end of the Corbières massif and the massif of La Clape.

- Sète to Montpellier: the Gardiole mountain and the border of the Cévennes.

- East of Marseilles to Toulon: the Couronne Massif and the Calanques.

- Antibes to the Italian frontier: the Préalpes of Grasse and of Nice.

The cave openings in these karstic environments have trapped sediments containing a variety of information about Quaternary human occupation and environment particularly over the last glacio-eustatic cycle (Billaud et al. 2014; Billaud 2017).

Underwater archaeological studies of these submerged karstic openings are still few in number. Apart from the recent operations in the Cosquer Cave (described below), there is older research conducted from 1968 to 1976 by DRASSM (Département des Recherches Archéologiques Sub-aquatiques et SousMarines), mainly focussed on the Calanques Marseillaises area and the Villefranche Bay further east (Bonifay 1970, 1973; Bonifay and Courtin 1998). In the Calanques, this research identified a dozen caves, but only four have been investigated in detail. One of them contains bone breccias, and Palaeolithic artefacts were discovered at another (Bonifay and Courtin 1998).

In the Couronne Massif, few cavities are mentioned apart from the Caves of the Mona au Rouet and the three Cap Méjean caves (Bonifay and Courtin 1998, fig. 2), which are openings at a depth of 15-20 m bpsl. Two of these are complex networks only partly explored. One contains cemented deposits which have yielded micro- 
fauna (Courtin 1978, p. 738). In the Var department, cavities are also mentioned east of $\mathrm{La}$ Ciotat (Courtin 1978). They are situated at a depth of 10-15 m bpsl and contain cemented deposits.

Information about the archaeology of these underwater karsts is uneven because, apart from the Cosquer Cave, they have often been explored for speleological or hydrological purposes rather than archaeological. Nevertheless, the available information indicates the presence of Pleistocene sedimentary sequences and remains of human activity and fauna, suggesting considerable potential for future research.

\subsubsection{The Cosquer Cave}

In 1991, the discovery of the Cosquer Cave, located on the coast near Cassis east of Marseille, revealed the only Palaeolithic painted cave known to this day east of the River Rhone. This resulted in renewed interest in the detailed study of regional karst and in the reconstruction of sealevel rise after the last glaciation. The Cosquer Cave has been visited by divers since 1984, but its archaeological significance was only formally recorded in 1991 (Clottes et al. 2005; Vanrell 2010). This cavity is presently accessible to divers by an opening at a depth of $37 \mathrm{~m}$ bpsl which leads upwards through a narrow gallery to a partially flooded chamber (Fig. 12.14). The original entrance was closed by sea-level rise after the Last Glacial Maximum. However, the water level in the cave is slightly lower than that of the Mediterranean Sea. The emerged part of the cave has provided a rich collection of art, with a total of 188 animal figures (11 species identified, some of which are marine species, including 9 seals, 4 fish and 3 auks), 71 negative handprints and nearly 300 symbolic representations (Fig. 12.15). There are numerous traces of past human activity-handprints, charcoal, hearths and broken concretions. Radiocarbon dates place the occupation between 29,000 and 17,500 BP (Early Gravettian to Epigravettian).

\subsection{Later Prehistoric Finds}

\subsubsection{Intertidal Settlements and Peat Deposits}

Ancient peat deposits are exposed at low tide along many shorelines and extend to the subtidal zone. They bear witness to the extension of backbarrier marshes before the end of postglacial sealevel rise.

On the shorelines of Picardie and Boulonnais, low, sandy beaches alternate with rocky headlands, with offshore gravel barriers or bay-mouth bars. On the sandy beaches, peat deposits exposed by marine erosion provide radiocarbon dates between $5700 \mathrm{BP}$, as in the Canche tidal creek in

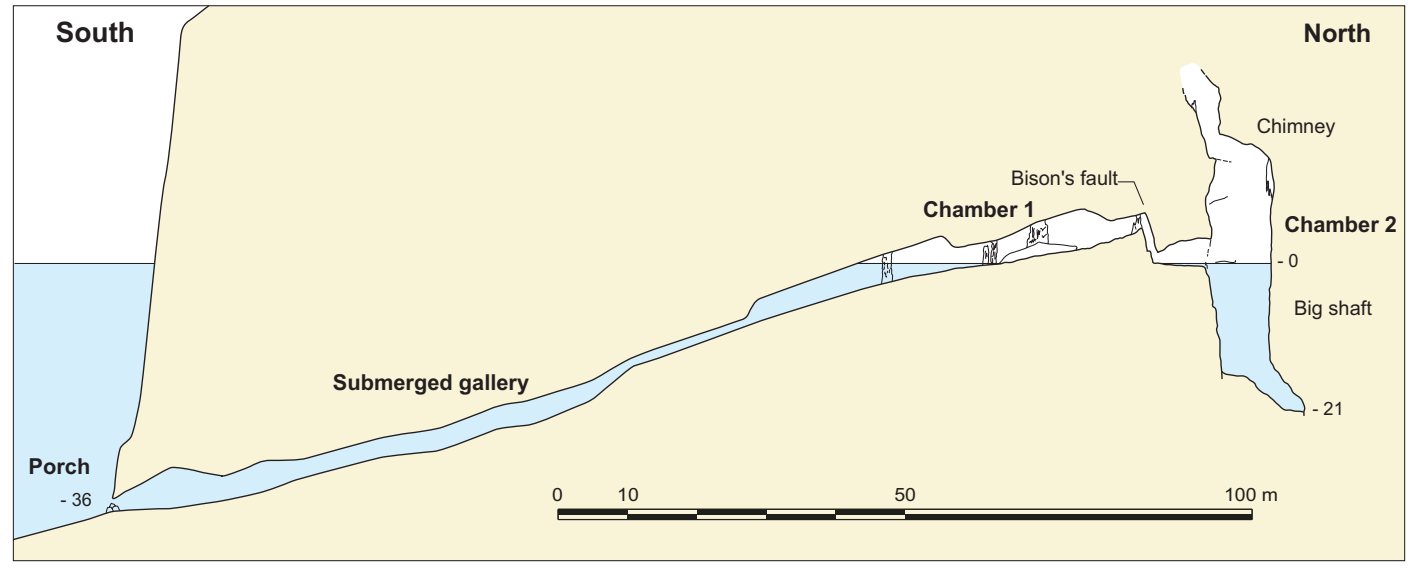

Fig. 12.14 Longitudinal cross-section through Cosquer Cave. Drawing by Yves Billaud 


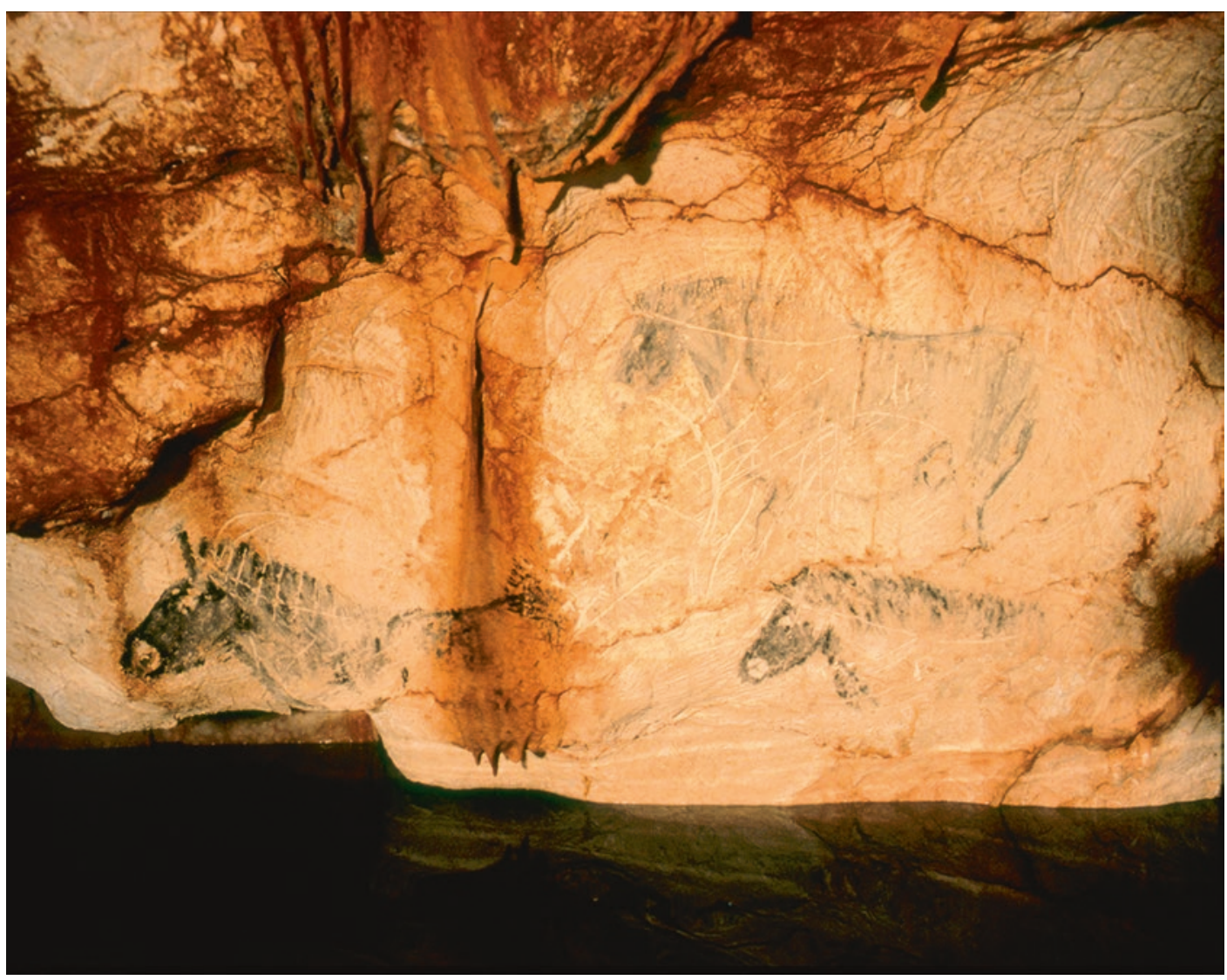

Fig. 12.15 Les Petits Chevaux, Cosquer Cave, operation DRASSM. Photo by Antoine Chené, CNRS

Camiers, and 3600 BP, as at Wimereux (Mariette 1971), sometimes associated with lithic artefacts as at Wissant's Bay (Dutertre 1924, 1925; Briquet 1930), and especially at Tardinghen (Mariette 1971, 1976b; Vallin and Masson 1993).

At Wimereux, the top of the eroded peat yielded flint implements and traces of a hearth (Briquet 1906, 1930; Dutertre 1925, 1930, 1933, 1934; Agache 1968; Mariette 1971). Also, a shell midden was recorded on the edge of the peat where it was covered by humic sands (Munaut and Gilot 1977), and the level beneath provided some sherds attributed to the Middle and Late Neolithic (Mariette 1971, 1976a; Ters 1973).

Similar deposits are present at Hardelot, about $20 \mathrm{~km}$ further south (Mariette 1971; Ters 1973; Agache 1968; Bostyn and Vallin 1986), where a Late Neolithic site has been discovered around $-2.5 \mathrm{~m}$ ODN. Remains of a rectangular building consisting of wooden poles dug in the peat were observed in the nineteenth century (Ovion 1890).

In Brittany, several Neolithic occupations have been identified in submerged peats: a deer antler industry at La Ville-Berneuf (in PléneufVal-André) (Milon and Giot 1949); the remains of postholes, ditches and varied implement dated to 4000-2500 cal BC at Curnic in Guissény (Giot et al. 1965); and Neolithic polished axes, flint tools and ceramics at the mouth of the Quillimadec River (Kerlouan).

On the right bank of the mouth of the Rance River, the remains of a probable settlement discovered at the limit of the present lowest tides yielded two lines of wooden stakes $50 \mathrm{~m}$ apart (Langouët 1995; Hénaff et al. 1998), and one of the stakes is dated to 3327-2929 cal BC (Ly8830), attributable to the Recent Neolithic. 
On the Vendée coastline, numerous peat deposits have been observed since the early twentieth century (Welsch 1911, 1917), especially at Brétignolles-sur-Mer, where Early Neolithic material has been recorded at La Parée, -5 and - 6 m ODN, dated at 5207-4458 cal BC, and at La Pointe du Grouin du Cou dated at 57004850 cal BC (Joussaume et al. 1986).

The Charente coastline has a different morphology, with a string of islands close offshore, and a continental shelf deeply incised by ancient valleys (Laporte 1998, 2009). There are rare discoveries of the 5th or early 4th millennium (cal. BC), notably the Early Neolithic remains at the Bois-en-Ré beach (Pautreau and Robert 1980) and a Middle Neolithic shell midden (Rousseau et al. 2001). Remains belonging to the later 4th and 3rd millennium are more abundant, reflecting the stabilisation of the shoreline at its present position. Submerged peats on the west coast of Oléron Island facing the mainland have produced many Late Neolithic finds (Welsch 1917; Burnez and Morel 1965; Gabet 1973; Laporte and Glausinger 1986; Laporte et al. 1998; Laporte 2009). At La Pointe d'Ors, there are the remains of a probable domestic stone building within archaeological levels accessible only at low tide (Luguet 1867; Pineau 1891; Boisselier 1893; Dulioust 1958; Gabet 1968; Rouvreau 1968; Rouvreau and Gomez 1973; Joussaume 1981; Cassen 1987; Laporte et al. 1995). These deposits have yielded some wooden artefacts, including examples of stone axes in wooden handles, and similar artefacts are reported on the opposite side of the same bay at Piédemont (Gabet and David 1975).

\subsubsection{Megalithic Sites}

\subsubsection{Neolithic Tombs}

Several passage graves are located at about mean tide level on the Channel coast. These are typically dated to about 5100 cal BP but may have continued in use until around 4000 cal BP (L'Helgouach 1965; Giot 1958, 1968; Giot and Morzadec 1992). The position of these monuments ranges between $0 \mathrm{~m}$ ODN (i.e., $+5,27 \mathrm{~m}$ above low tide) and $-7 \mathrm{~m}$ ODN. Because of the tidal range, these monuments are regularly submerged, in some cases at every high tide, as with the Kernic passage grave at Plouescat (Fig. 12.16). This monument is probably one of the most famous on the northern coast of Brittany. Classified as a 'monument historique', it was excavated in 1983 and 1984 because of the effects of shoreline erosion and was then restored (Lecerf 1985).

On the shore, to the south of Coalen Island (Lanmodez, Côtes-d'Armor), there is a damaged passage grave, which has lost its capstones (Fig. 12.16). Open to the south, the monument is reached during higher tides. It is $7.2 \mathrm{~m}$ long and $1.4 \mathrm{~m}$ wide and still has 3 standing stones on the west side and 6 on the east. To the north, an isolated half block constitutes perhaps one of the
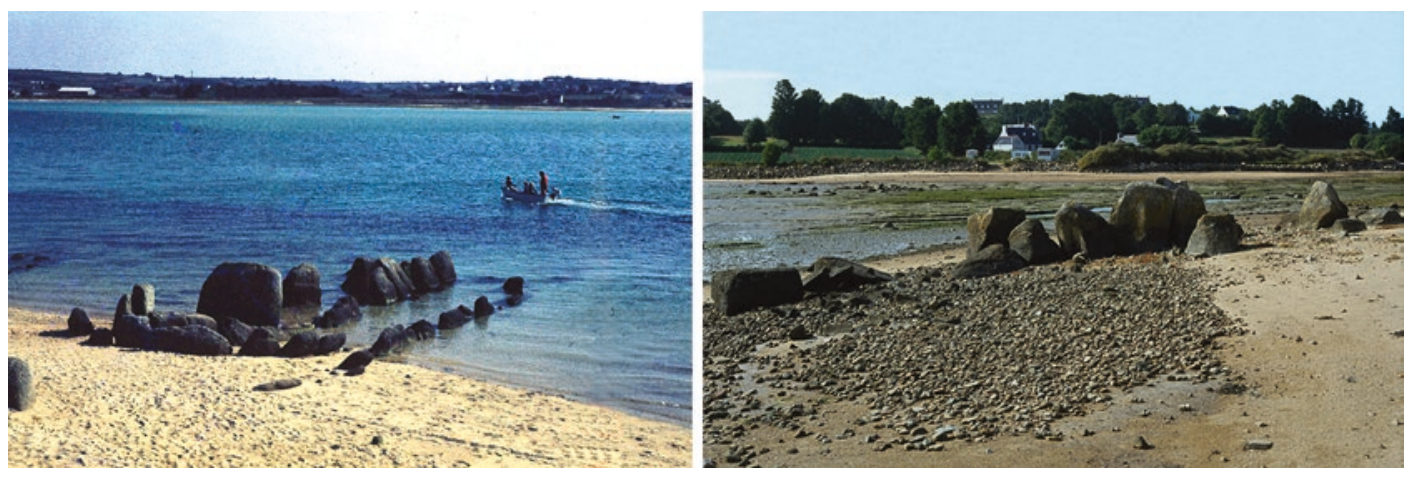

Fig. 12.16 Partially submerged passage graves on the seashore. Left: Kernic, Plouescat (Finistère); Right: Coalen Island in Lanmodez (Côtes d'Armor). Photos by Marie-Yvane Daire 
sides of a terminal chamber ('cella'), and scattered blocks may be the remains of the surrounding structure (Giot 1971).

In the channel between Rovarc'h and Garec'h-Vari islands (Penvenan, Côtesd'Armor), a collapsed dolmen stands on the shore of Pellinec. In the 1930s, a flagstone measuring $1.80 \times 1.60 \mathrm{~m}$ and 5 supports lying on the ground could still be seen (Mazères and de Bellaing 1936). In the same commune, the channel of Saint-Gildas island (Penvenan) presents on its south side an eroded and collapsed dolmen, which was still visible at the beginning of the 1930s (Mazères and de Bellaing 1936). In the 1980s, only some scattered blocks remained (Daire, personal observation).

On the north bank of Tresseny Bay, there is a probable passage grave at Lerret in Kerlouan, submerged at each high tide, though much damaged. The monument as a whole, the northern side of which is well preserved, is $23 \mathrm{~m}$ long (L'Helgouach 1965; Sparfel and Pailler dir. 2009, pp. 100-101). At Le Conquet on the northern point of Finistère, around forty flagstones indicating a likely collapsed passage grave are visible at low tide on the beach of Les Blancs Sablons (Sparfel and Pailler dir. 2009, p. 175). Four of them are oriented in the same direction, forming a passage with an internal width of $1.7 \mathrm{~m}$.

East of Noirmoutier Island (Vendée), the stone called 'La Table' is the only remnant of a dolmen (Large et al. 2015).

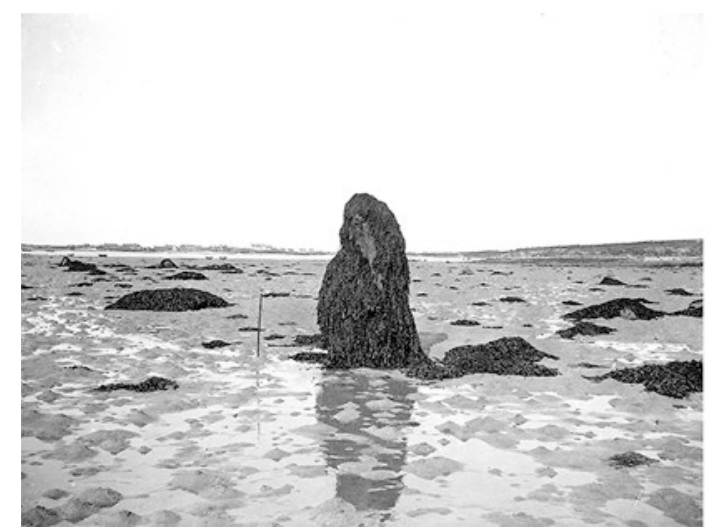

\subsubsection{Standing Stones and Megalithic Complexes}

In several places in Brittany, submerged standing stones mark the seashore and are important amongst other reasons because they are evidence of Holocene marine transgression. In many cases, these stones appear in isolation-all that is left of the original monument complex-but sometimes sufficient numbers are present to indicate a circular layout.

At Côte des Abers (Finistère), several megalithic monuments on the seashore include the 2.5-m high-standing stone of Saint-Cava Bay in Plouguerneau, called Men Ozac'h (Devoir 1912). Before being moved, it was submerged for half the tidal cycle with the base lying $2 \mathrm{~m}$ above present mean sea level (Fig. 12.17). This standing stone was associated with the remains of a rectangular enclosure of smaller blocks.

On the south coast of Finistère, the standing stone of Penglaouiic (Loctudy), in the PontL'Abbé river, is partly submerged at high tide. It is one of a series of megaliths placed at the mouth of waterways or streams, notably at Lesconil (Fig. 12.17), Léchiagat and Lespurit en Plovan.

Other examples are the large menhir currently lying on the ground on the south of Groix Island in Locmaria Bay, some dozens of metres offshore from the present coastline (López-Romero et al. 2008), and in Brittany, the standing stones of La Pointe du Chevet at Saint-Jacut-de-la-Mer (Côtes-d'Armor) (Langouët 2003) and

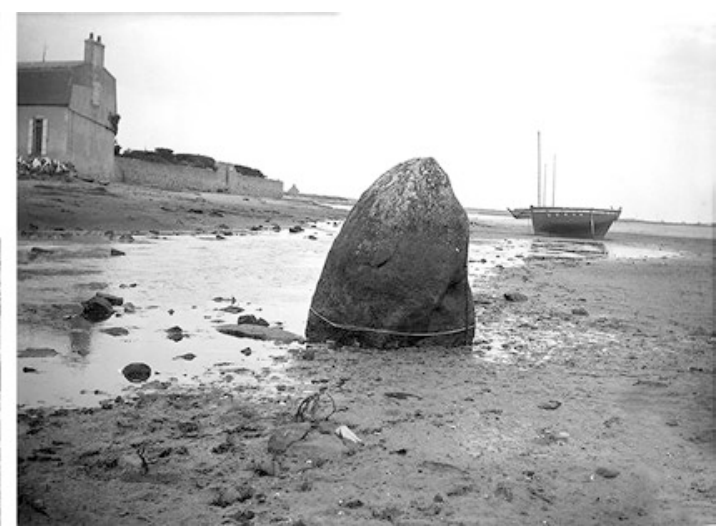

Fig. 12.17 Left: Menhirs on the Finistère coast. Left: Men Ozarc'h at Plouguerneau. Right: Lesconil. Photos courtesy of Archives du Labo Archéosciences, UMR 6566 CreAAH, Rennes 
Trébeurden, located between Grande Island and Milliau Island (Marchat and Le Brozec 1991).

\subsubsection{Stone Rows and Megalithic Enclosures}

Several partly submerged standing stones have recently been discovered and studied in Morbihan, especially on the seashore of the Quiberon Peninsula, such as the Kerdual alignment, preserved between Carnac and La Trinité-sur-Mer, and the Kerpenhir site (Locmariaquer). Highlighted by Z. Le Rouzic (1965), a set of submerged blocks has long been seen extending into the sea at low tide, a prolongation of the Le Moulin alignments (Saint-Pierre-Quiberon). These include more than a dozen parallel lines of standing stones about $400 \mathrm{~m}$ long, associated with a megalithic enclosure (2 large stelae are still visible) and a burial mound. Mapping of the rocky Kerbougnec platform also led to the discovery of a subtidal structure comprising 150 partly submerged monoliths (Cassen et al. 2011).

At Le Petit-Rohu in Quiberon, two pairs of polished axe blades made from Alpine rock embedded in the mud of the foreshore were discovered by holidaymakers in August 2007 at Porh Fetan (Fig. 12.18; Cassen et al. 2008). Further to this discovery, excavations revealed animal footprints, plough marks and a set of 45 collapsed flagstones, which appear to have formed a NNE-SSW alignment. Some of these are visible on the shore at low spring tide, and others are permanently submerged in 5-6 m water. There are numerous other stone rows of similar type in the same area, such as Kerbougnec, which are now submerged in more than $5 \mathrm{~m}$ of water. The environmental context shows that the axe blades associated with the Petit-Rohu monoliths were buried in wetlands behind a sandy barrier at the foot of a prominent rocky outcrop. The coastline would have been about $500 \mathrm{~m}$ distant at

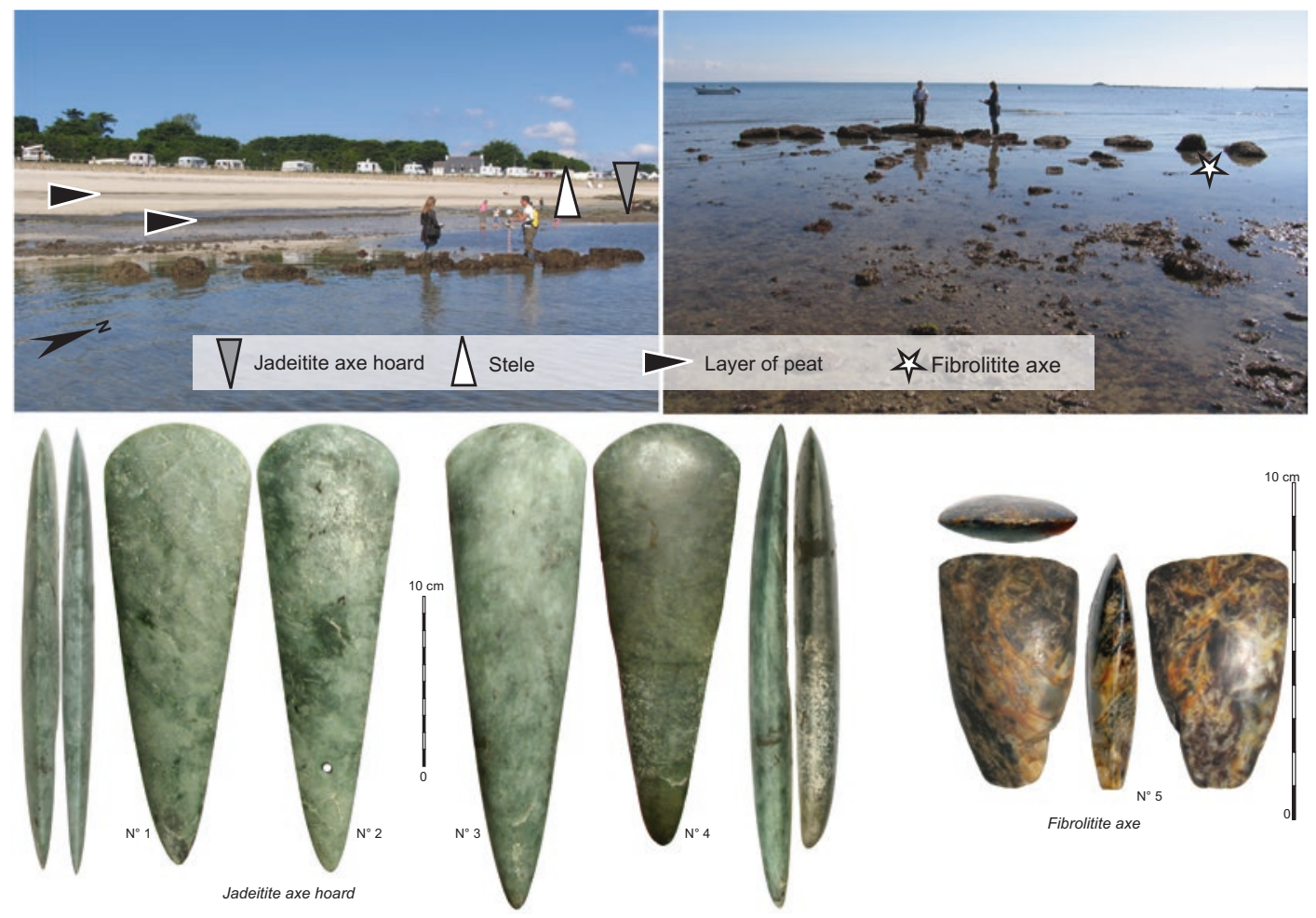

Fig. 12.18 Rows of stelae discovered at low tide on the intertidal platform of Le Rohu in Saint-Pierre-Quiberon and a hoard of jadeite axes. After Cassen et al. (2010) 
the time when these artefacts were deposited, estimated on archaeological grounds as the mid5th millennium cal BC (Cassen et al. 2010).

At the heart of the Morbihan Gulf is the famous double megalithic enclosure of Er Lannic, long recognised as evidence of a Holocene marine transgression (Closmadeuc 1882). Erected around $6000 \mathrm{cal} \mathrm{BP}$, this consists of 49 menhirs, of which 33 are covered at high tide (Gouezin 1998). They form two adjacent horseshoe-shaped enclosures, with a menhir, larger than the others, standing at the point where they meet (Fig. 12.19).

Finally, a cromlech (circle of standing stones) occurs on the Chausey archipelago (Manche). The archipelago was separated from the mainland about $5000-4000$ cal BC by a shallow (c. $20-\mathrm{m}$ deep) sea crossing of $14 \mathrm{~km}$. The tidal range in this area is $15 \mathrm{~m}$, and at low tide near the Oeillet inlet, there is a rocky seashore with the cromlech located at around $-0.2 \mathrm{~m}$ ODN (Fig. 12.19; Chancerel et al. 1994, 1998). This circle (a little flattened) is composed of large granite boulders, of which only five are still in their vertical position. Inside the circle, there is an oval-shaped stone-lined hearth $1.25 \mathrm{~m}$ long. Around 600 flint artefacts recovered from the site confirm a Neolithic date. There are also several stone dikes related to the cromlech, which could be contemporaneous with it.

\subsubsection{Coastal Lagoons}

\subsubsection{The Atlantic Coast}

The coastal lagoons here are well known for their submerged finds, especially from the protohistoric period in the Sanguinet Lake (Maurin 1998). However, the Aquitaine region also offers evidence of several prehistoric sites around the Arcachon Basin and the ancient mouth of the Leyre River. The Betey site in Andernos-LesBains is characterised by numerous discoveries made during pedestrian surveys on the shoreline, but without stratigraphic or chronological context (Roussot-Larroque 1997). The subsequent study of the artefacts has indicated four main occupation phases: Mesolithic and Early, Recent and Late Neolithic.

Excavations associated with new harbour work in the area (carried out jointly by INRAP, DRASSM and Aquitaine SRA) have produced stratified and radiocarbon-dated evidence of Neolithic sherds and lithics as well as sherds of Early Bronze Age II/Middle Bronze Age I, although this material has been subjected to redeposition by fluvial action.

\subsubsection{The Mediterranean}

A number of submerged Neolithic finds have been found in coastal lagoons (Leroy 2001). One of the principal sites is Leucate-Corrège discovered by dredging at a depth of $-5 \mathrm{~m}$, which includes Early Neolithic material including fish and bird bone, net weights and bone tools (Guilaine et al. 1984). Middle and Late Neolithic settlements have also been recovered at Montpenèdre in Marseillan, in the Thau lagoon, Moutaras at La Grande Motte and Frontignan 'Les Dunes' at depths ranging from 0 to $-2 \mathrm{~m}$ (Montjardin and Cablat 2004) and at Mèze 'La Conque'. Several Bronze Age sites are present in these coastal contexts, especially in the Thau lagoon (Leroy et al. 2003).

\subsubsection{Submerged Fish Weirs}

Fish weirs have been systematically studied in Brittany since 2006 (Daire and Langouët 2008; Langouët and Daire 2009; Daire and Langouët 2010; Daire et al. 2013; Gandois and Stéphan 2015; Gandois et al. 2018), and similar inventories have begun in the Departments of Manche (Normandy) and Vendée (Pays de Loire) since 2009. To date, in Brittany, more than 750 fish weirs have been identified and characterised by twenty or so variables, such as the type of weir, length and level in relation to tides (Table 12.2). Most, of course, relate to the present position of the shoreline and are relatively late in date.

The oldest wooden fish weirs are located in the Bay of Mont-Saint-Michel at the mouth of the Rance River and are radiocarbon-dated to the 

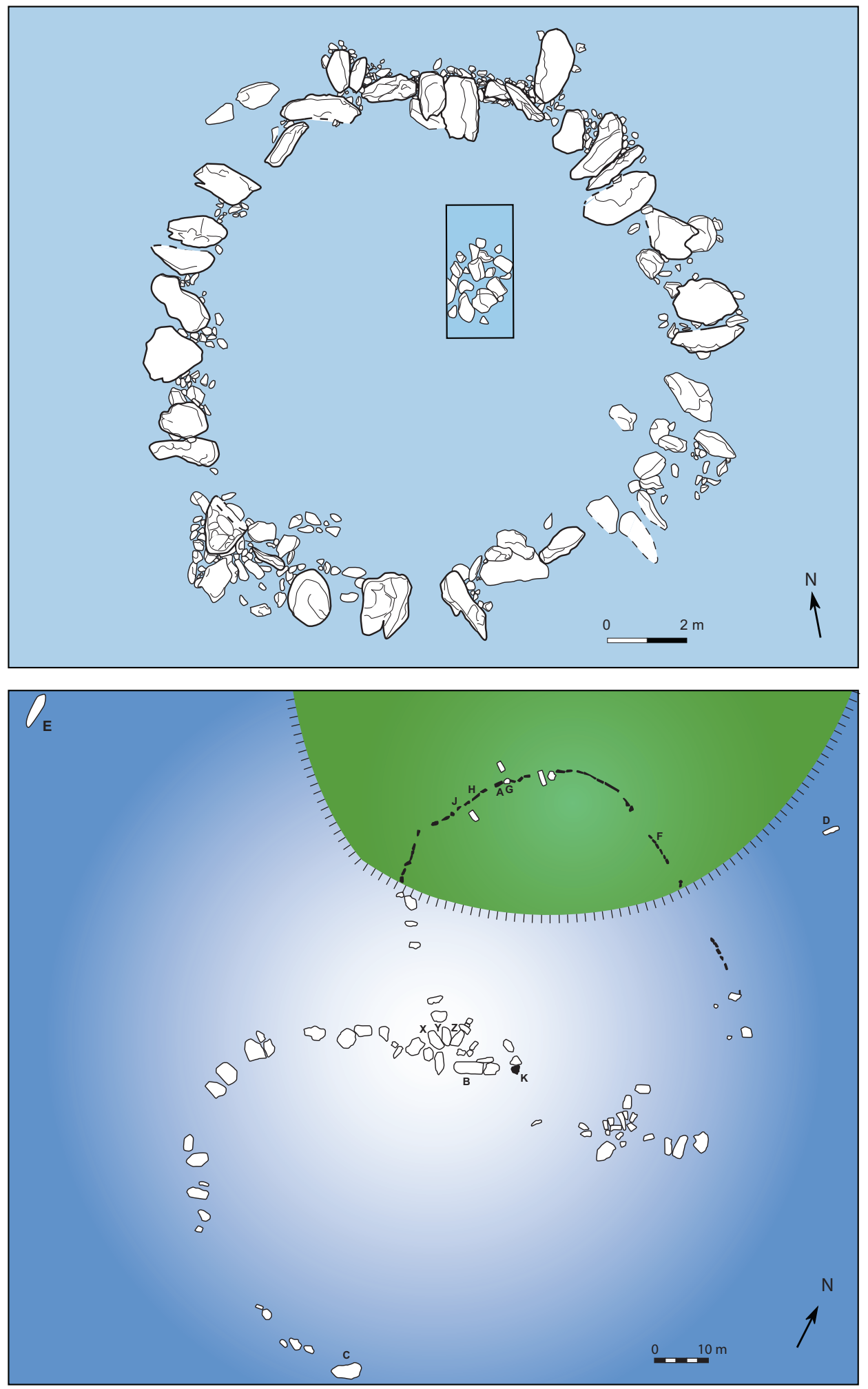

Fig. 12.19 Lower: General diagram of the megalithic enclosures of Er Lannic, Morbihan (after P. Gouezin 1998). Upper: The cromlech of L'Oeillet on the Chausey archipelago (Manche). After Chancerel et al. (1994, 1998). Drawing by G Lannuzel 
Table 12.2 Inventory of fish weirs of all periods in Brittany, from the database 'Pêcheries d'Estran de Bretagne', 2017

\begin{tabular}{l|l|l|l|l|l}
\hline & $\begin{array}{l}\text { Côtes- } \\
\text { d'Armor }\end{array}$ & Finistère & Morbihan & $\begin{array}{l}\text { Ille-et- } \\
\text { Vilaine }\end{array}$ & $\begin{array}{l}\text { Brittany } \\
\text { Total }\end{array}$ \\
\hline Fish weirs of all types and periods & 304 & 246 & 121 & 84 & $\mathbf{7 5 5}$ \\
\hline Wooden fish weirs of all periods & 45 & 3 & 14 & 60 & $\mathbf{1 2 2}$ \\
\hline Stone fish weirs of all periods & 239 & 226 & 82 & 23 & $\mathbf{5 7 0}$ \\
\hline $\begin{array}{l}\text { Stone fish weirs below the level of the lowest spring } \\
\text { tide } \% \text { of all stone fish weirs in parentheses) }\end{array}$ & $5(2.1)$ & $66(29.2)$ & $10(12.2)$ & $2(8.7)$ & $\mathbf{8 3 ( 1 4 . 6 )}$
\end{tabular}

This database is in progress and is not yet published. It includes additional finds of fish weirs, listed in this table, but these are not included in Table 12.1

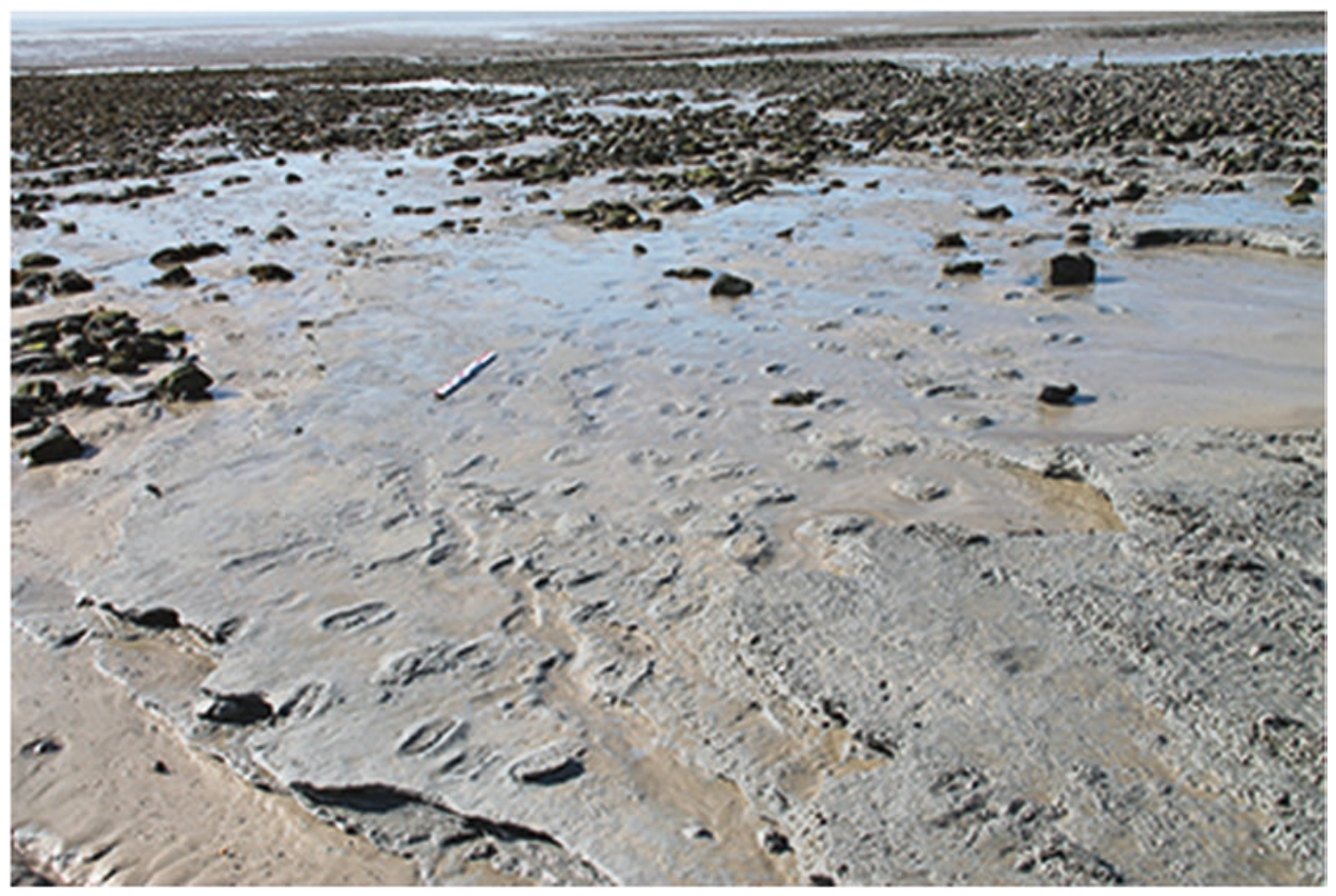

Fig. 12.20 Footprints at Saint-Jean-le-Thomas (Manche). They are associated with the remains of a wooden fish weir (not visible in the image) of Late Neolithic or Early Bronze Age. The scale is $1 \mathrm{~m}$. Photo by Cyrille Billard

Late Neolithic (Hénaff et al. 1998). Early Bronze Age examples are known at Saint-Jean-leThomas and Champeaux (Manche) (Fig. 12.20; Billard et al. 2013a, b; all radiocarbon dates in Billard and Bernard dir. 2016).

In Brittany, the search for ancient stone fish weirs, principally conducted from aerial photos of the shore at low tide, has led to the identification of fish weirs under 3-4 m of water. Similar submerged examples have also been observed along the coasts of Vendée and Normandy, four sites and 11 sites, respectively (Fig. 12.21; Large et al. 2009; Billard et al. 2016).

Dating of stone fish weirs is a problem, but a broad dating scheme is possible by relating the position of the weirs to present-day tidal level with reference to the Holocene sea-level curve of the region (Daire and Langouët 2010, 2011, Daire et al. 2013). Those that are permanently submerged must have been built when relative sea level was lower than present and can be attributed to the Mesolithic or Neolithic period. In 


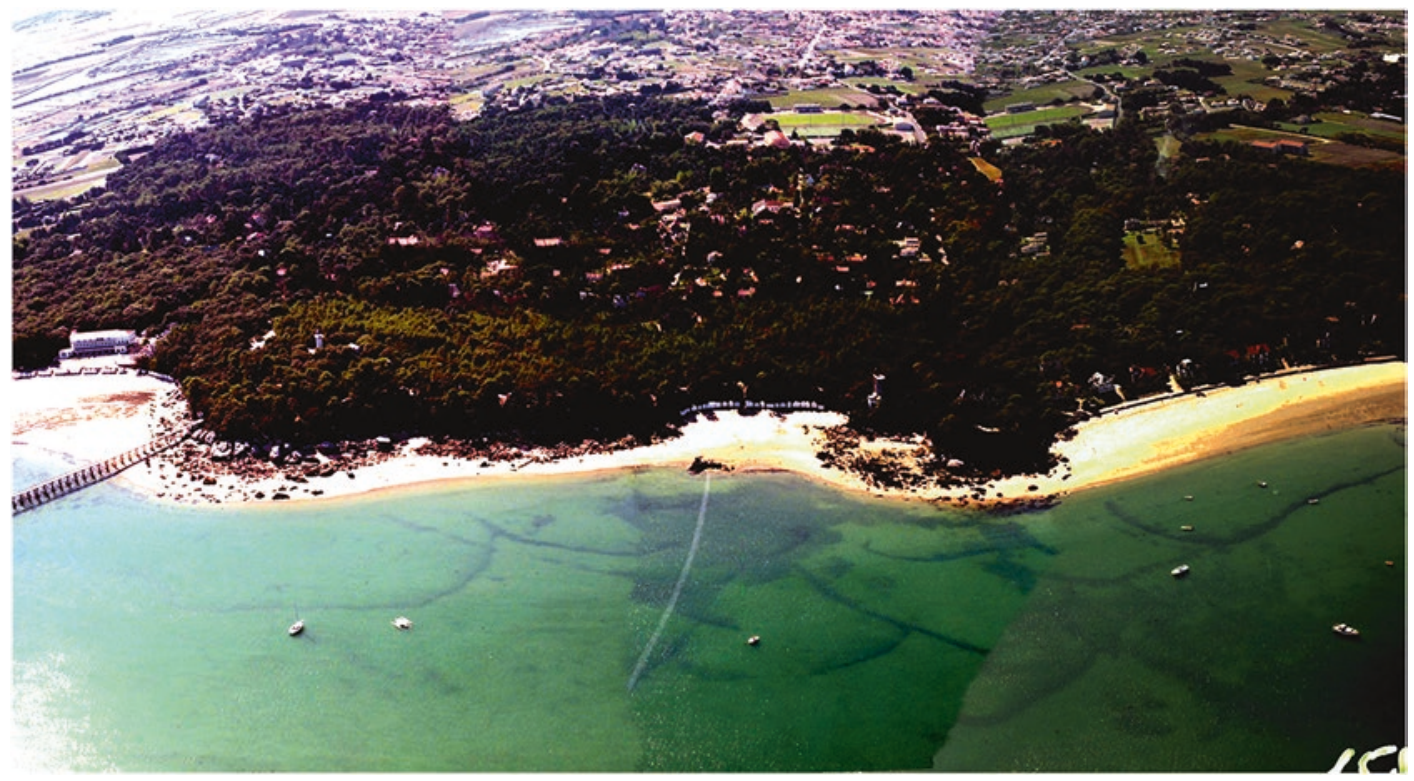

Fig. 12.21 Submerged complex of fish weirs at Le Tambourin, Noirmoutier Island (Vendée). Photo by Patrice Birocheau, 2009
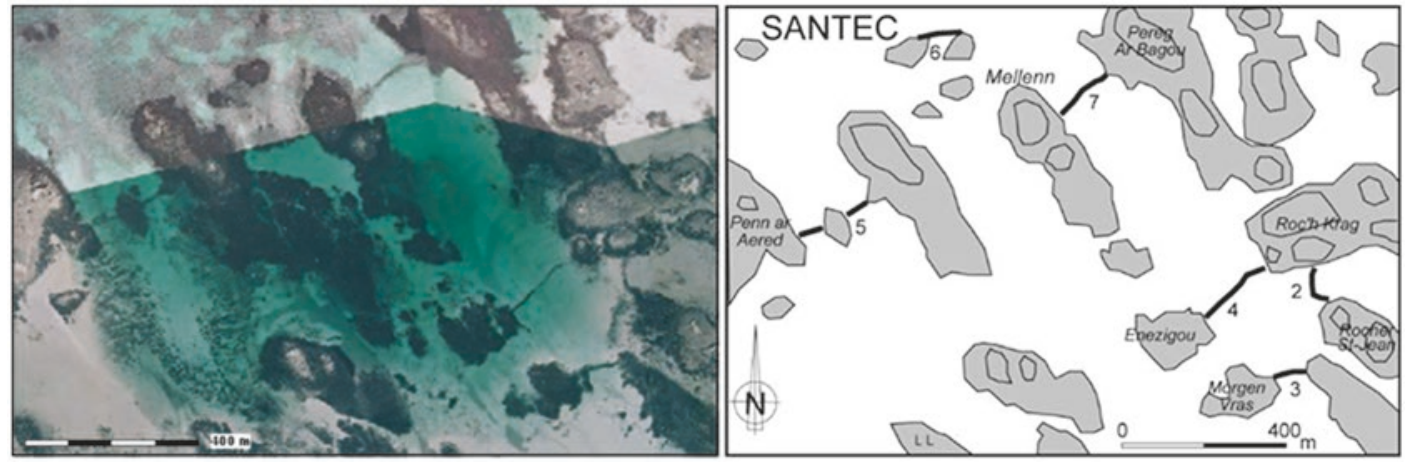

Fig. 12.22 Three submerged fish weirs at Santec (Finistère). They are built across a submarine channel delimited by the rocks marked Melenn et Pereg ar Bagou and form a sequence at progressively shallower depths ( 7 is deepest, 3 is shallowest), illustrating the adaptation of the fish weir builders to progressive sea level rise. Photo by Ortholittorale 2000; drawing by Loïc Langouët

Brittany, 83 of these have been identified, $14.6 \%$ of all known stone fish weirs in the region (Table 12.2). The majority are located on the channel coasts of Finistère, Côtes d'Armor and Ille et Vilaine, with far fewer on the Atlantic coastlines. The oldest, judging by their depth at $\mathrm{c}$. $5 \mathrm{~m}$ below the spring tide level, are at Lag Karreg (Brignogan) and Telleskog (Kerlouan) in Finistère.
In some areas, 'horizontal stratigraphies' can be observed, that is, shifts in the position of fish weirs to accommodate the rise in sea level. At Santec, three fish weirs are located at progressively shallower depths from $-6.8 \mathrm{~m}$ to $-2.6 \mathrm{~m}$ along a submerged valley channelled between rocky outcrops (Fig. 12.22; Roué and Le Goff 2008 , p. 105). In the same way, at Saint-Jean-dela-Rivière (Manche), six stone fish weirs form a 


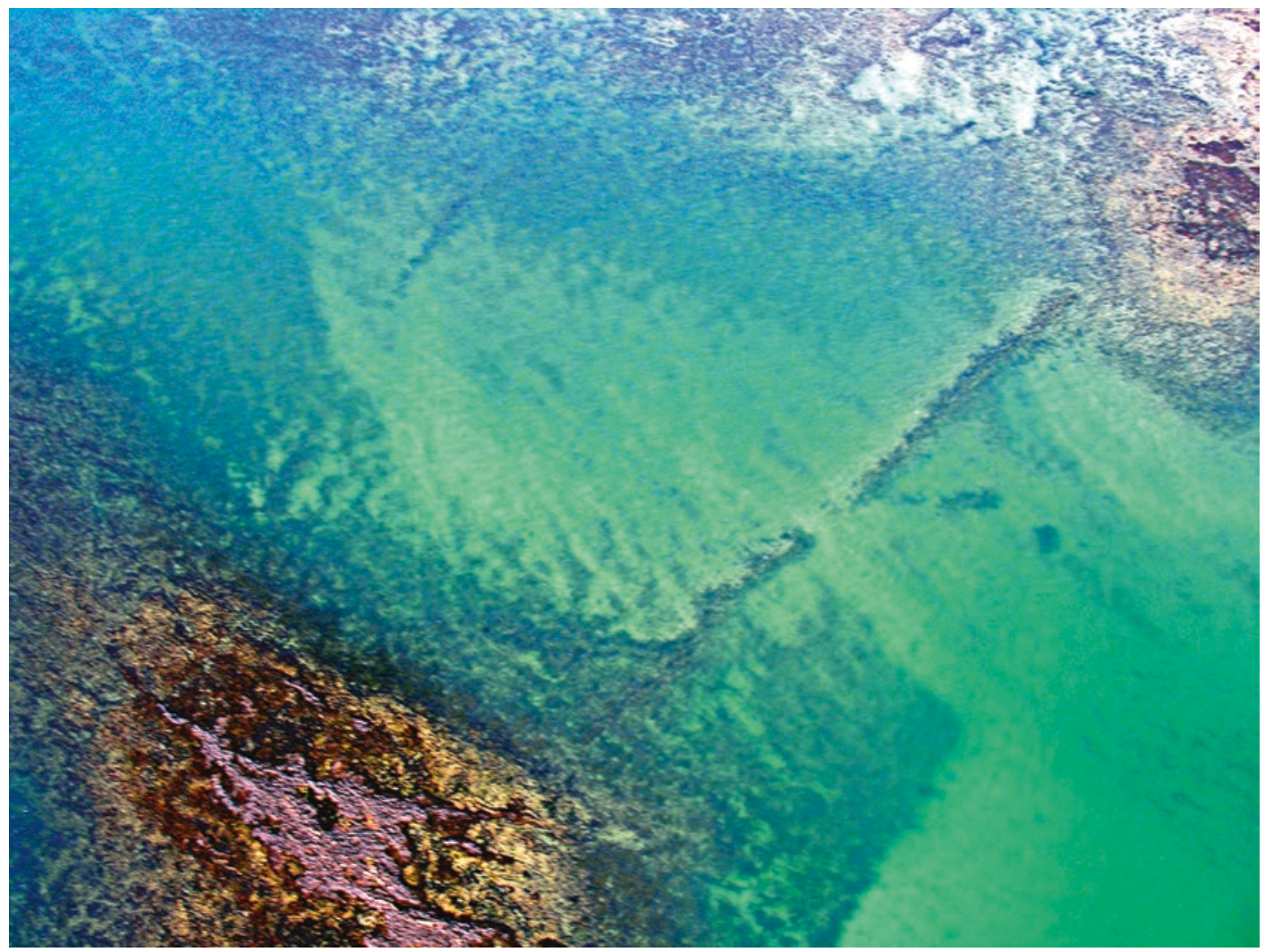

Fig. 12.23 Submerged fish weir complex at L'Épine, Noirmoutier Island (Vendée). Photo by Patrice Birocheau, 2009

sequence of successively shallower structures across a marine channel, the lowest being fully subtidal and the highest being located close to the neap tide level.

It is probable that many more submerged stone fish weirs remain to be discovered on other coastlines, and surveys are only just beginning, as, for example, at L'Acheneau (Vendée), where the fish weir is submerged at -3 to $-9 \mathrm{~m}$ (Fig. 12.23; Ydier and De Maisonneuve 2012), and in the Molène archipelago (Gandois et al. 2013a, b).

\subsection{Scientific Challenges and Future Prospects}

Prehistoric occupations have left significant traces in the intertidal zone and on the seabed, but until recently in France, as in many European countries, maritime archaeology has principally involved the study of ships and maritime trade. However, archaeological investigations along the coastline have successfully confirmed the high potential and good preservation of submerged sites, including organic artefacts such as wooden objects, features related to fishing and faunal assemblages. New types of sites and new problems have emerged in the past decade. The potential for the investigation of submerged Palaeolithic sites is highlighted by the Fermanville ' $\mathrm{La}$ Mondrée' site and the famous Cosquer Cave. The study of megalithic complexes needs to be extended offshore to obtain a more complete picture, and fish weirs are producing an unexpectedly abundant and informative indicator of widespread and intensive activity along the Atlantic and Channel coastlines. In many areas of western France, submerged coastal sites represent one of the principal ways to obtain tree ring 
series for the construction of dendrochronological reference curves.

Little work has been carried out so far on high-resolution mapping of submerged landscapes, and this should be a priority for the future. Bathymetric lidar, in particular, offers interesting prospects for surveys in shallow water. Other priorities are the integration of palaeoenvironmental studies with archaeological survey, particularly in relation to the Pleistocene, and the training of divers who combine diving qualifications with a knowledge of prehistoric archaeology. The implementation of a genuine scientific programme relating to all these issues is all the more urgent in that offshore industrial projects, including wind farms, the quarrying of marine aggregates and the expansion of port areas, are rapidly increasing along the French coastline.

\subsection{Management of the Underwater Cultural Heritage}

The underwater heritage has been the responsibility of DRASSM (Département des Recherches Archéologiques Subaquatiques et Sous-marines) since 1966. This is a national government agency under the ministry in charge of culture and is based at Marseille. It is responsible for the implementation of legislation relating to all aspects of maritime cultural heritage including prehistoric, archaeological and historical information, with particular reference to the intertidal area and the seabed within the French exclusive economic zone, especially since the ratification by France in 2013 of the 2001 UNESCO Convention. DRASSM registers sites and directs the study and excavation of submarine archaeological sites in France and overseas. It includes freshwater contexts within its remit and is concerned with the evaluation and study of sites as varied as shipwrecks, prehistoric lacustrine dwellings, river installations and submerged caves.

\section{References}

Agache R (1968) Informations archéologiques, circonscription de Nord et Picardie. Gallia-Préhistoire 9(2):267-309

Antoine P (1989) Stratigraphie des formations pléistocènes de Sangatte (Pas-de-Calais), d'après les premiers travaux du tunnel sous la Manche. Bulletin de l'Association Française pour l'Etude du. Quaternaire 37:5-17

Antoine P, Auguste P, Bahain JJ, Louguet S (2011) Datation et reconstitution paléoenvironnementale d'un site paléolithique moyen submergé en Manche Est: Ault-Onival (Somme, France). Quaternaire 22(3):221-233

Auguste P (2009) Evolution des peuplements mammaliens en Europe du Nord-Ouest durant le Pléistocène moyen et supérieur. Le cas de la France septentrionale. Quaternaire 20(4):527-550

Babeau L (1906) La préhistoire et la plage sous-marine du Havre. Bulletin de la Société Géologique de Normandie 26:37-45

Bahain JJ, Flaguières $\mathrm{C}$, Laurent $\mathrm{M}$, Shao $\mathrm{Q}$, Dolo JM, Garcia T, Douville E, Frank N, Monnier JL, Hallegouet B, Laforge M, Huet B, Auguste P, Serre F, Gangnepain J (2012) ESR and ESR/U-series dating study of the Middle Paleolithic site of Piégu (Brittany, France) - a multi-material approach. Quat Geochronol 10:424-429

Balescu S, Packman SC, Wintle AG, Grün R (1992) Thermoluminescence dating of the middle Pleistocene raised beach of Sangatte (Northern France). Quat Res 37(3):390-396

Bernard J, Visset L (1992) Une tourbière interglaciaire sur la plage de la Parée à Brétignolles (Vendée - France): première approche pollenanalytique. Quaternaire 3:16-22

Bertran P, Sitzia L, Banks WE, Bateman MD, Demars PY, Hernandez M, Lenoir M, Mercier M, Prodeo F (2013) The Landes de Gascogne (Southwest France): periglacial desert and cultural frontier during the Palaeolithic. J Archaeol Sci 40(5):2274-2285

Billard C, Bernard V (2016) Pêcheries de Normandie: Archéologie et histoire des pêcheries littorales du département de la Manche. Presses Universitaires de Rennes, collection Archéologie et Culture, Rennes, $717 \mathrm{p}$

Billard C, Bernard V, Bouffigny A, Clavel B, Couturier Y, Jaouen G, Le Digol Y, Quevillon S, Ropars A (2013a) Techniques et modes d'exploitation des pêcheries sur le littoral normand (France) : un essai de bilan de 10 années de travaux archéologiques. In: Daire MY, Dupont C, Baudry A, Billard C, Large JM, Lespez L, Normand E, Scarre C (eds) Ancient maritime communities and the relationship between people and environment along the European Atlantic coasts. 
Proceedings of the HOMER 2011 conference, Vannes, 28 septembre-1er octobre 2011, British archaeological reports international series 2570. Archaeopress, Oxford, pp 139-149

Billard C, Bernard V, Quevillon S (2013b) Potentiel et méthodes d'approche des pêcheries littorales de Basse-Normandie (France). In: Daire MY, Dupont C, Baudry A, Billard C, Large JM, Lespez L, Normand E, Scarre C (eds) Ancient maritime communities and the relationship between people and environment along the European Atlantic coasts. Proceedings of the HOMER 2011 conference, Vannes, 28 septembre-1er octobre 2011, British archaeological reports international series 2570. Archaeopress, Oxford, pp 3-11

Billard C, Daire MY, Martin C, Billaud Y, Bizien-Jaglin C, Chancerel A, Cliquet D, Fourment N, Gandois H, Huet B, Laforge M, Langouët L, Laporte L, Large JM, Leroy F, López-Romero E, Monnier JL, Ropars A, Régaldo P, Stéphan P, Vallin L (2016) Un premier inventaire des sites préhistoriques submergés au large des côtes françaises. Bulletin de l'Association Manche Atlantique pour la Recherche Archéologique dans les Iles 29:5-49

Billaud Y (2017) Submerged karst structures of the French Mediterranean coast: an assessment. In: Flemming NC, Harff J, Moura D, Burgess A, Bailey GN (eds) Submerged landscapes of the European continental shelf: Quaternary Paleoenvironments. Wiley, Chichester, pp 333-340

Billaud Y, Chazaly B, Olive M, Vanrell L (2014) Acquisition 3D et documentation multiscalaire de la grotte Cosquer: une réponse aux difficultés d'accès et à une submersion inéluctable? Kartologia 64:7-16

Boisselier A (1893) Le palet de Gargantua et les oscillations du niveau de la mer. Revue des Sciences Naturelles de l'Ouest 3:366-367

Bonifay E (1970) Antiquités archéologiques sousmarines. Gallia Préhistoire 13(2):585-592

Bonifay E (1973) Circonscription des antiquités préhistoriques sous-marines. Gallia Préhistoire 16(2):525-533

Bonifay E, Courtin J (1998) Les remplissages des grottes immergées de la région de Marseille. In: Camps G (ed) L'homme préhistorique et la mer, $120^{\mathrm{e}}$ congrès du commité des travaux historiques et scientifiques, Aix-en-Provence, oct. 1995. Editions du Commité des Travaux Historiques et Scientifques, Paris, pp 11-29

Bostyn F, Vallin L (1986) L'outillage préhistorique en os du Nord-Pas-de-Calais. Inventaire et aspects techniques. Gallia Préhistoire 29(1):193-215

Briquet A (1906) Notes sur quelques formations quaternaires du littoral du Pas-de-Calais. Annales de la Société Géologique du Nord 35:211-236

Briquet A (1930) Le littoral du nord de la France et son évolution morphologique. Editions A. Colin, Paris

Burnez C, Morel J (1965) Contribution à la connaissance de la céramique préhistorique de la Saintonge. Bulletin de Société Prehistorique Française 62/63:555-566
Cassen S (1987) Le Centre-Ouest de la France au IVe millénaire, British archaeological reports international series 342. Archaeopress, Oxford

Cassen S, Boujot C, Errera MD, Marguerie D, Menier D, Pailler Y, Pétrequin P, Poirier S, Veyrat E, Vigier E (2008) Discovery of an underwater deposit of Neolithic polished axeheads and a submerged stone alignment at Petit Rohu near Saint-Pierre-Quiberon (Morbihan, France). Antiquity 82, Project Gallery. http://www. antiquity.ac.uk/projgall/cassen316/

Cassen S, Boujot C, Errera MD, Menier D, Pailler Y, Pétrequin P, Marguerie D, Veyrat E, Vigier E, Poirier S, Dagneau C, Degez D, Lorho T, Neveu-Derotrie H, Obeltz C, Scalliet F, Sparfel Y (2010) Un dépôt sous-marin de lames polies néolithiques en jadéitite et sillimanite et un ouvrage de stèles submergé sur la plage dite du Petit Rohu près Saint-Pierre-Quiberon (Morbihan). Bulletin de Société Prehistorique Française 107:53-84

Cassen S, Baltzer A, Lorin A, Fournier J, Sellier D (2011) Submarine Neolithic stone rows near Carnac (Morbihan, France): preliminary results from acoustic and underwater survey. In: Benjamin J, Bonsall C, Pickard C, Fisher A (eds) Submerged prehistory. Underwater archaeology and the future of submerged European prehistory. Oxbow, Oxford, pp 99-110

Chancerel A, Hérard B, Ghesquière E, Desloges J (1994) Archipel de Chausey. Rapport de prospection 1994. DRAC service régional de l'archéologie, Caen

Chancerel A, Dinard F, Desloges J, Ghesquière E, Hérard B (1998) Archipel de Chausey (Granville - Manche). Rapport de prospection. Campagne de 1996. DRAC service régional de l'archéologie, Caen

Cliquet D, Coutard S, Clet-Pellerin M, Allix J, Tessier B, Lelong F, Baltzer A, Mear Y, Poizot E, Auguste P, Alix P, Olive J, Guesnon J (2011) The Middle Palaeolithic underwater site of La Mondrée, Normandy, France. In: Benjamin J, Bonsall C, Pickard C, Fisher A (eds) Submerged prehistory. Underwater archaeology and the future of submerged European prehistory. Oxbow, Oxford, pp 111-128

Closmadeuc G (1882) Le cromlech d'Er-Lannic et le Golfe du Morbihan, à l'époque dite celtique. Bulletin de la Société Polymathique du Morbihan 1882:8-24

Clottes J, Courtin J, Vanrell L (2005) Cosquer redécouvert. Seuil, Paris

Courtin J (1978) Recherches Archéologiques sousmarines. Gallia Préhistoire 21(2):735-746

Coutard S (2003) Formations quaternaires en bordure d'une mer épicontinentale, la Manche Tectonique, eustatisme, climat et occupations humaines - Exemple du Val de Saire (Normandie, France). Unpublished $\mathrm{PhD}$ thesis, Université Caen Normandie, Caen

Coutard S, Cliquet D (2005) Chronostratigraphie des formations pléistocènes et peuplement paléolithique en contexte littoral (Val de Saire, Normandie). Bulletin de Société Prehistorique Française 102:477-499 
Daire MY, Langouët L (eds) (2008) Les pêcheries de Bretagne; archéologie et Histoire des pêcheries d'estran. Co-édition CeRAA-AMARAI, Les Dossiers du Centre Régional d'Archéologie d'Alet, AE

Daire, MY, Langouët, MY (2010) Les anciens pièges à poissons des côtes de Bretagne, un patrimoine au rythme des marées. Co-édition CeRAA-AMARAI, Les Dossiers du Centre Régional d'Archéologie d'Alet, AG

Daire MY, Langouët L (2011) Dater les anciennes pêcheries par les niveaux marins: approches méthodologiques et perspectives géo-archéologiques: le Bas-Léon, nord Finistère, Bretagne. Norois 220:3-25

Daire MY, Langouët L, Maheo M (2013) Une archéologie au rythme des marées: actualité des recherches sur les anciens barrages de pêcheries maritimes en Bretagne (France). In: Daire MY, Dupont C, Baudry A, Billard C, Large JM, Lespez L, Normand E, Scarre C (eds) Ancient maritime communities and the relationship between people and environment along the European Atlantic coasts. Proceedings of the HOMER 2011 conference, Vannes, British archaeological reports international series 2570. Archaeopress, Oxford, pp 151-162

Devoir A (1912) Témoins mégalithiques des variations des lignes de rivages armoricains. Bulletin de la Société Archéologique du Finistère 39:220-239

Dréano Y, Gandois H, Pailler Y (2013) L'exploitation des poissons dans l'archipel de Molène (Finistère, France) du Néolithique récent à l'Âge du Bronze ancien. In: Daire MY, Dupont C, Baudry A, Billard C, Large JM, Lespez L, Normand E, Scarre C (eds) Ancient maritime communities and the relationship between people and environment along the European Atlantic coasts. Proceedings of the HOMER 2011 conference, Vannes, British archaeological reports international series 2570. Archaeopress, Oxford, pp 447-458

Dulioust JP (1958) La station d'Ors. Bulletin de la Société Préhistorique Française 55(5/6):262-263

Dutertre AP (1924) Observations sur les formations quaternaires et récentes du Boulonnais. Annales du Musée géologique du Boulonnais 1(4):3-13

Dutertre AP (1925) Notice géologique sur la Pointe aux Oies et les abords de la station zoologique de Wimereux. Travaux de la Station Zoologique de Wimereux 9:66-88

Dutertre AP (1930) Trouvailles dans la tourbe submergée de la Pointe-aux-Oies, près Wimereux (Boulonnais). Annales de la Société Géologique du Nord 55:19-21

Dutertre AP (1933) L'industrie et la faune de la tourbe submergée du rivage du Boulonnais (Note préliminaire). Bulletin de la Société Préhistorique Française 30(11):587-588

Dutertre AP (1934) Notice archéologique sur la tourbe submergée de la Pointe-aux-Oies à Wimereux (Pas-deCalais). Bulletin de la Société Préhistorique Française 31(7/8):352-359

Facon R (1967) Présence du Moustérien moyen, type La Quina à l'Île Madame (Charente-Maritime). Bulletin de la Société Préhistorique Française 64:275-278
Farr RH, Momber G, Satchell J, Flemming NC (2017) Paleolandscapes of the Celtic Sea and the Channel/ La Manche. In: Flemming NC, Harff J, Moura D, Burgess A, Bailey GN (eds) Submerged landscapes of the European continental shelf: Quaternary Paleoenvironments. Wiley, Chichester, pp 211-239

Fridman R (1957) Généralités sur des phénomènes périglaciaires würmiens sur le littoral et les îles de la Charente-maritime. Bulletin de la Société Géographique de Rochefort 7:585-596

Gabet C (1968) Habitat néolithique d'Ors. Bulletin de la Société de Géographie de Rochefort, 2e série, 4

Gabet C (1973) Le Banc de Tourbe sur l'estran de la baie de La Perroche (île d'Oléron). Bulletin de la Société Archéologique et Historique de la Charente Maritime 25:297-307

Gabet C, David P (1975) Le gisement de Piédemont (Commune de Port-des-Barques). Rapport préliminaire. Roccafortis 2e série, III 6:177-193

Gandois H, Stéphan P (2015) Les barrages de pêcheries de l'archipel de Molène (mer d'Iroise, Finistère). Bulletin de l'Association Manche Atlantique pour la Recherche Archéologique dans les Îles 28:45-76

Gandois H (dir.), Stéphan P, Cuisnier D, Gladu Y, Lallement F, Priol H (2013a) Rapport sur les prospections sous-marines et la zone d'estran en mer d'Iroise, Opération n ${ }^{\circ} \mathrm{OA}-1746$. DRASSM, SRA Bretagne

Gandois H, Pailler Y, Stéphan Y, Nicolas C (2013b) L'érosion marine et ses effets sur les vestiges archéologiques en mer d'Iroise: exemple de l'impact de la tempête de mars 2008 sur l'île Kemenez et ses Ledenez (Le Conquet, Finistère, France). In: Daire MY, Dupont C, Baudry A, Billard C, Large JM, Lespez L, Normand E, Scarre C (eds) Ancient maritime communities and the relationship between people and environment along the European Atlantic coasts. Proceedings of the HOMER 2011 conference, Vannes, British archaeological reports international series 2570. Archaeopress, Oxford, pp 99-110

Gandois H, Stéphan P, Cuisnier D, Hulot O, Ehrhold A, Paul M, Le Dantec N, Franzetti M (2018) The stone tidal fish weirs of the Molène archipelago (Iroise Sea, Brittany, Western France): a long-term tradition starting with early megalithic constructions. Int $\mathrm{J}$ Naut Archaeol 47(1):5-27

Giot PR (1958) Kernic, Plouescat. Gallia Préhistoire 1(1):129

Giot PR (1968) La Bretagne au péril des mers holocènes. In: La Préhistoire, problèmes et tendances. CNRS, Paris, pp 203-208

Giot PR (1971) Lanmodez, île Coalen. Gallia Préhistoire $14: 341$

Giot PR, Morzadec H (1992) Des dolmens à couloirs au péril des mers actuelles. Revue Archéologique de l'Ouest 9:57-66

Giot PR, Hallegouët B, Briard G (1965) Le site du Curnic en Guissény (Finistère). Annales de Bretagne 72(1):49-70 
Giot PR, Hallegouët B, Monnier JL (1973) Le Paléolithique ancien du Pays de Léon. Finistère L'Anthropologie 77:497-518

Goslin J, Van Vliet-Lanoë B, Spada G, Bradley S, Tarasov L, Neill S, Suanez S (2015) A new Holocene relative sea-level curve for western Brittany (France): insights on isostatic dynamics along the Atlantic coasts of North-Western Europe. Quat Sci Rev 129:341-365

Gouezin P (1998) Le site mégalithique d'Er Lannic. Editions de l'Association Archéo Douar Mor, Vannes

Guilaine J, Freises A, Montjardin R (1984) LeucateCorrège, habitat noyé du Néolithique ancien cardial. Archives d'Ecologie Préhistorique. Centre d'anthropologie des sociétés rurales, Toulouse, musée Paul Valéry, Sète

Guillaume L (1935) Observations sur les dépôts quaternaires de Saint-Côme-de-Fresné et Asnelles-BellePlage (Calvados). Bulletin de la Société Linéenne de Normandie 8(8):63-72

Guillaume L (1952) Les formations quaternaires de la plage du débarquement britannique de Saint-Côme de Fresné-Asnelles Belle Plage (Calvados). In: Shackleton RM (ed) Part XIII. Proceedings of section M. Other subjects, international geological congress, report of the eighteenth session, Great Britain, 1948, London, pp 105-113

Harff J, Flemming NC, Groh A, Hünicke B, Lericolais G, Meschede M, Rosentau A, Sakellariou D, Uścinowicz S, Zhang W, Zorita E (2017) Sea level and climate. In: Flemming NC, Harff J, Moura D, Burgess A, Bailey GN (eds) Submerged landscapes of the European continental shelf: quaternary paleoenvironments. John Wiley \& Sons, Chichester, pp11-49

Hénaff X, Langouët L, Meury JL (1998) Des structures néolithiques en bois dans l'anse du Rosais à SaintMalo (35), suite. Bulletin de l'Association Manche Atlantique pour la Recherche Archéologique dans les Îles 11:5-11

Hinout J, Rolland C (1960) Gisements côtiers de SaintTrojan. Bulletin de la Société Préhistorique Française 57(5/6):27

Huet B (2002) Une industrie à composante lithologique mixte: le gisement paléolithique moyen de Goaréva (île de Bréhat, Côtes-d'Armor). Bulletin de la Société Préhistorique Française 99:699-716

Huet B (2006) De l'influence des matières premières lithiques sur les comportements techno-économiques au Paléolithique moyen: l'exemple du Massif armoricain (France). Unpublished $\mathrm{PhD}$ thesis Université Rennes 1, Rennes

Huet B (ed) (2010) Le site paléolithique moyen des Vallées (Pléneuf-Val-André, Côtes-d'Armor) Rapport de fouille archéologique programmée, DRASSM et SRA Bretagne

Joussaume R (1981) Le Néolithique de l'Aunis et du Poitou occidental dans son cadre atlantique, Rennes, Travaux du Laboratoire d'Anthropologie-PréhistoireProtohistoire et Quaternaire Armoricains. CNRS, Paris Joussaume R, Boiral M, Ters M (1986) Sites préhistoriques submergés à La Tranche-sur-Mer (Vendée).
Bulletin de la Société Préhistorique Française 83(11/12):423-435

Labrude C, Large JM, Mangematin J (2000) Le Marais Girard à Brétignolles-sur-Mer (Vendée): une nouvelle approche du site. Bulletin du Groupe Vendéen d'Etudes Préhistoriques 36:13-23

Laforge M (2012) Le cadre chronostratigraphique des peuplements pléistocènes de l'Ouest de la France. Eustatisme, changements climatiques et occupations humaines. Unpublished $\mathrm{PhD}$ thesis Université de Rennes 1, Rennes

Laisné G, Vilgrain G (2008) Quand Néandertal occupait le littoral de Portbail (Manche). Rapport PCR "Les Premiers Hommes en Normandie", septième année

Lambeck K, Esat TM, Potter EK (2002) Links between climate and sea-levels for the past three million years. Nature 419:199-206

Lambeck K, Rouby H, Purcell A, Sun Y, Sambridge M (2014) Sea level and global ice volumes from the last glacial maximum to the Holocene. Proc Natl Acad Sci 111:15296-15303

Langouët L (1995) Des structures néolithiques en bois dans l'anse du Rosais à Saint-Malo (35). Bulletin de l'Association Manche Atlantique pour la Recherche Archéologique dans les Îles 8:27-32

Langouët L (2003) Les menhirs de Saint-Jacut-de-la-Mer. Bulletin de l'Association Manche Atlantique pour la Recherche Archéologique dans les Îles 16:61-65

Langouët L, Daire MY (2009) Ancient maritime fish-traps of Brittany (France): a reappraisal of the relationship between human and coastal environment during the Holocene. J Marit Archaeol 4(2):131-148

Laporte L (ed) (1998) L'estuaire de la Charente de la Protohistoire au Moyen Age. Document d'Archéologie Française. Editions de la Maison des Sciences de 1'Homme, Paris

Laporte L (ed) (2009) Des premiers paysans aux premiers métallurgistes dur la façade atlantique de la France (3500-2000 av. JC). Mémoire XXXIII, Editions de l'Association des Publications Chauvinoises

Laporte L, Glausinger R (1986) Le site de L'Ecuissière à Dolus (île d'Oléron, Charente-Maritime). Groupe Vendéen d'Etudes Préhistoriques, La Roche-sur-Yon, pp 77-88

Laporte L, Regibus JP, Regibus J, Ricou C, Rodien-Laire C (1995) Inventaire archéologique de l'île d'Oléron (17). Bulletin de l'Association Manche Atlantique pour la Recherche Archéologique dans les Îles 8:5-20

Laporte L, Cros JP, Fontugne M, Gebhardt A, Gruet Y, Marguerie D, Oberlin C (1998) Les occupations néolithiques de la côte occidentale de l'île d'Oléron. In: Camps G (ed) L'homme préhistorique et la mer, Actes du $120^{\mathrm{e}}$ Congrès National des Sociétés Savantes, Aixen-Provence, 1995. Congrès National des Sociétés Historiques et Scientifiques, Paris, pp 197-238

Large JM, Birocheau P, Corson S, Cousseau F, Large C, Tortuyaux JP (2009) Une archéologie des pêcheries d'estran. L'anse aux Moines et la Pointe du Vieux Moulin au Château-d'Olonne en Vendée Bulletin du Groupe Vendéen d'Etudes Préhistoriques 45:4-45 
Large JM, Corson S, Magne J (2015) Le mégalithe de la Table sur le Plateau de la Vendette (Noirmoutier-en L'Île, Vendée). Bulletin du Groupe Vendéen d'Etudes Préhistoriques 51:33-41

Le Rouzic Z (1965) Les monuments mégalithiques de Carnac et de Locmariaquer. Leur destination - Leur âge. Imprimerie Armoricaine, Quimper

Lecerf Y (1985) L'allée couverte de Kernic à Plouescat (Finistère). Bulletin de la Société Archéologique du Finistère 114:17-34

Lefort JP, Hallegouêt B, Monnier JL (2011) La mer d'Iroise: une singularité dans l'approvisionnement en silex des hommes du Paléolithique. Revue Archéologique de l'Ouest 28:7-18

Leroy F (2001) Sites lagunaires du Languedoc au Néolithique et à l'Âge du bronze. In: L'Helgouach J, Briard J (eds) Systèmes fluviaux, estuaires et implantations humaines de la Préhistoire aux grandes invasions, actes du $124^{\mathrm{e}}$ congrès national des sociétés historiques et scientifiques, Nantes, 1999. Congrès National des Sociétés Historiques et Scientifiques, Paris, pp 229-239

Leroy F, Bouby L, Guibal F (2003) Les gisements protohistoriques de l'étang de Thau. In: Actes des quatrièmes rencontres méridionales de Préhistoire récente, Nîmes 2000, pp 369-376

L'Helgouach, J (1965) Les Sépultures mégalithiques en Armorique (dolmens à couloirs et allées couvertes). Unpublished PhD thesis, Université de Rennes 1, Rennes

Lopez-Romero E, Langouët L, Bihan S (2008) Nouveaux mégalithes sur l'Ile de Groix. Bulletin de l'Association Manche Atlantique pour la Recherche Archéologique dans les Îles 21:5-14

Luguet H (1867) Note sur des recherches faites dans l'île d'Oléron. Recueil de la Commission des Arts et Monuments Historiques de la Charente-Inférieure 2:301-304

Marchat A, Le Brozec M (1991) Les mégalithes de 1'arrondissement de Lannion. Collection Patrimoine archéologique de Bretagne, Institut Culturel de Bretagne et Travaux du Laboratoire d'AnthropologiePréhistoire de Rennes, Rennes

Mariette H (1971) L'Archéologie des dépôts flandriens du Boulonnais. Quaternaria 14:137-150

Mariette H (1976a) Le Néolithique de la Pointe-auxOies (Wimereux, Pas-de-Calais). In: Livret-guide de l'excursion A10 du IXe Congrès de l'UISPP (Nice, 1976): Nord-Ouest de la France (Bassin de la Seine, Bassin de la Somme et Nord), pp 172-173

Mariette H (1976b) Flandrien et archéologie de Wissant (Pas-de-Calais). In: Livret-guide de l'excursion A10 du IXe Congrès de l'UISPP (Nice, 1976): Nord-Ouest de la France (Bassin de la Seine, Bassin de la Somme et Nord), pp 180-182

Maufras E (1874) Du préhistorique de la CharenteInférieure (deux stations néolithiques à l'île d'Oléron). Association Française pour l'Avancement des Sciences, Congrès de Lille, pp 590-593
Maurin B (1998) 3000 ans sous les eaux: vingt ans de fouilles archéologiques dans le lac de Sanguinet, Landes. Editions Gaia, Paris

Mazères R, de Bellaing E (1936) Port-Blanc en Penvénan. Aperçu géologique et préhistorique. Bulletin de la Société d'Emulation des Côtes-du-Nord LXVIII:195-213

Mercier J (1934) Observations sur les gisements d'Elephas primigenius Blum. en Basse-Normandie. Bulletin de la Société Linnéenne de Normandie, 8ème série 6:7-11

Mercier N, Cliquet D, Olive J, Poudret-Barré A, Momber G, Coutard S, Clet M (2013) Approche du gisement moyen sous-marin de la Mondrée à Fermanville (Manche) et évaluation de son potentiel en matière de datation par la méthode de l'OSL. In: Daire MY, Dupont C, Baudry A, Billard C, Large JM, Lespez L, Normand E, Scarre C (eds) Ancient maritime communities and the relationship between people and environment along the European Atlantic coasts. Proceedings of the HOMER 2011 conference, Vannes, British archaeological reports international series 2570. Archaeopress, Oxford, pp 13-22

Michel D, Coutard JP, Helluin M, Lautridou JP, Ozouf JC, Pellerin J (1982) Contribution à l'étude du Paléolithique inférieur et moyen de la région de Barfleur. Le Paléolithique inférieur de GattevillePhare (Manche). Bulletin de la Société Préhistorique Française 79(10/12):319-329

Milon Y, Giot PR (1949) IVe Circonscription, informations archéologiques. Gallia Préhistoire 7(2):252-256

Monnier JL (1986) Le gisement paléolithique moyen de Nantois, Pléneuf (Côtes-du-Nord). Bulletin de la Société Préhistorique Française 83:146-150

Monnier JL (1988) Le gisement paléolithique moyen des Gastines (Ille-et-Vilaine). Etude géologique et archéologique. Revue archéologique de l'Ouest 5:11-33

Monnier JL (2006) Les premiers peuplements de l'Ouest de la France. Cadre chronostratigraphique et paléoenvironnemental. Bulletin du Musée d'Anthropologie et Préhistoire de Monaco 46:3-20

Monnier JL, Huet B, Laforge M (2011) Application of sedimentological analysis to correlation of eroded layers under beaches with local and regional Pleistocene stratigraphy. A contribution to geological dating of Palaeolithic sites on the northern coast of Brittany (France). Quat Int 231:78-94

Montjardin R, Cablat A (2004) Le gisement Néolithique ancien des Dunes à Frontignan (Hérault). In: Dartevelle H (ed) Auvergne et Midi. Actes des Vème Rencontres Méridionales de Préhistoire Récente (Clermont-Ferrand, Novembre 2002). Préhistoire du Sud-Ouest, supplément 9:295-312

Morzadec-Kerfourn MT (1974) Variation de la ligne de rivage armoricaine au Quaternaire. Analyses polliniques de dépôts organiques littoraux. Mémoires de la Société Géologique et Minéralogique de Bretagne 17 
Munaut AV, Gilot E (1977) Recherches palynologiques et datations $14 \mathrm{C}$ dans les régions côtières du Nord de la France. I. Phases transgressives et stabilisations dunaires flandriennes dans l'estuaire de la Canche (Pasde-Calais). Bulletin de 1'Association Française pour l'Etude du Quaternaire 3:17-25

Néraudeau D, Bourgeois D (1994) Le Paléolithique inférieur et moyen de l'île Madame (17). Bulletin de l'Association Manche Atlantique pour la Recherche Archéologique dans les Îles 7:5-14

Ovion Dr (1890) Procès-verbal de la séance du 5 septembre 1888. Bulletin de la Société Académique de 1'Arrondissement de Boulogne-sur-Mer 5:372-373

Pailler Y, Stéphan P, Gandois H, Nicolas C, Sparfel Y, Tresset A, Donnart K, Dréano Y, Fichaut B, Suanez S, Dupont C, Audouard L, Marcoux N, Mougne C, Salanova L, Sellami F, Dietsch-Sellami MF (2014) Landscape evolution and human settlement in the Iroise Sea (Finistère, Brittany, France) during the Neolithic and bronze age. Proceedings of the Prehistoric Society 8:105-139

Pautreau JP, Robert PP (1980) Le foyer néolithique ancien des Gouillauds, au Bois, Île de Ré (CharenteMaritime). Bulletin de la Société Préhistorique Française 77(4):123-128

Perpère M (1986) Apport de la typométrie à la définition des éclats Levallois: l'exemple d'Ault. Bulletin de la Société Préhistorique Française 83(4):115-118

Perpère M (1999) Le débitage Levallois d'Ault. Anthropologie 103(3):343-376

Pineau E (1891) Nouvelle contribution à la géographie préhistorique des côtes occidentales de France. Bulletin de la Société Française pour l'Avancement des Sciences 1891:266-267

Pouit D, Viaud JM (2002) Des éléphants antiques (Palaeoloxodon antiquus) à Brétignolles-sur-Mer (Vendée, France): histoire et conséquences des découvertes. Le Naturaliste Vendéen 2:35-59

Pruvost P (2006) Le Paléolithique moyen des Iles Chausey (Manche). Rapport d'activité 2005 du PCR "Les Premiers Hommes en Normandie", pp 27-35

Romain G (1915) La station paléolithique sous-marine dans la plage du Havre. 43e session de l'Association Française pour l'Avancement des Sciences, Le Havre 1914, pp 611-619

Roué D, Le Goff JC (2008) Barrages à poissons et pêcheries à Santec (Nord-Finistère). In: Daire MY, Langouët L (eds) Les pêcheries de Bretagne: archéologie et histoire des pêcheries d'estran, Coéd. Ce.R.A.A.A.M.A.R.A.A.I., Les Dossiers du Centre Régional d'Archéologie d'Alet, AE, pp 97-111

Rousseau J, Robert PP, Cantin N, Dupont C (2001) Exploitation du territoire insulaire au Néolithique moyen d'après la fouille d'un amas coquillier. Les Gouillauds à Bois-plage en Ré (Charente-Maritime, France). Revue d'Archéométrie 25:225-242

Roussot-Larroque J (1997) La "station sous-marine" du Bétey à Andernos (Gironde) d'après la collec- tion Ferrier. Fédération Historique du Sud-Ouest, Bordeaux, pp 53-71

Rouvreau M (1968) Les fouilles de la Pointe d'Ors. Archéologie Pontoise

Rouvreau M, Gomez J (1973) Les occupations postnéolithiques de la station d'Ors (île d'Oléron). Bulletin de la Société d'Archéologie et d'Histoire de l'Aunis 25:37-44

Sauvage H-E (1899) Le mammouth de la partie sud de la Mer du Nord. Bulletin de la Société académique de l'arrondissement de Boulogne-sur-mer 5(1891-1899):408-416

Scuvée F, Vérague J (1988) Le gisement sous marin du Paléolithique moyen de l'anse de la Mondrée à Fermanville (Manche). LITTUS-C.E.H.P, Cherbourg

Sorrel P, Debret M, Billeaud I, Jaccard SL, Mc Manus JF, Tessier B (2012) Persistent non-solar forcing of Holocene storm dynamics in coastal sedimentary archives. Nat Geosci 5:892-896

Sparfel Y, Pailler Y dir. with contributions of Chaigneau C, Chauris L, Fichaut B, Gouletquer P, Stéphan P, Suanez S, Tanguy B (2009) Les mégalithes de l'arrondissement de Brest, inventaire et essai de synthèse. Editions CeRAA et Institut Culturel de Bretagne, Daint-Malo

Stéphan P (2011) Colmatage sédimentaire des marais maritimes et variations relatives du niveau marin au cours des 6000 dernières années en rade de Brest (Finistère). Norois 220:9-37

Stéphan P (2012) Une régression marine au Bronze final en Bretagne ? Ou le reflet de changements morphosédimentaires importants à la côte. In: M. Melin \& C. Mougne (dir.), L'homme, ses ressources et son environnement dans le Nord-ouest de la France à l'âge du Bronze: actualité de la recherche, Actes du séminaire archéologique de l'ouest du 22 mars 2012. Editions de Géosciences Rennes, hors-série 7, pp 131-139

Stéphan P, Goslin J (2014) Evolution du niveau marin relatif à l'Holocène le long des côtes françaises de l'Atlantique et de la Manche: réactualisation des données par la méthode des "sea-level index points". Quaternaire 25(4):295-312

Stéphan P, Pailler Y, Tresset A, Gandois H (2013) Changements paléogéographiques de l'archipel de Molène (Finistère, Bretagne, France): Implications sur les peuplements humains du Néolithique à l'Age du Bronze. In: Daire MY, Dupont C, Baudry A, Billard C, Large JM, Lespez L, Normand E, Scarre C (eds) Ancient maritime communities and the relationship between people and environment along the European Atlantic coasts. Proceedings of the HOMER 2011 conference, Vannes, British archaeological reports international series 2570. Archaeopress, Oxford, pp 647-660

Stéphan P, Goslin J, Pailler Y, Manceau R, Suanez S, Van Vliet-Lanoë B, Hénaff A, Delacourt C (2015) Holocene salt-marsh sedimentary infillings and relative sea-level changes in West Brittany (France) 
from foraminifera-based transfer functions. Boreas 44(1):153-177

Ters M (1973) Les variations du niveau marin depuis 10.000 ans, le long du littoral atlantique français. In: Le Quaternaire, géodynamique, stratigraphie, environnement. Travaux français récents. 9e Congrès INQUA, Christchurch. Supplement. Bulletin de 1'Association Française pour l'Etude du Quaternaire:114-115

Ters M (1986) Variations in Holocene Sea level on the French Atlantic coast and their climatic significance. In: Rampino MR, Sanders JE, Newman WS, Königsson LK (eds) Climate: history, periodicity and predictability. Van Nostrand Reinhold, New York, pp 204-237

Toucanne S (2008) Reconstruction des transferts sédimentaires en provenance du système glaciaire de mer d'Irlande et du paléofleuve Manche au cours des derniers cycles climatiques. Unpublished $\mathrm{PhD}$ thesis Université Bordeaux 1, Bordeaux
Vallin L, Masson B (1993) Tardinghem, dunes du Chatelet. Bilan Scientifique Régional du Nord-Pasde-Calais 80

Vanrell L (2010) La grotte Cosquer (Marseille, Bouchesdu-Rhône). In: Archéologie des rivages méditerranéens: 50 ans de recherches: actes du colloque d'Arles (Bouches-du-Rhône) 28-29-30 octobre 2009. Errance, Paris, pp 31-36

Welsch J (1911) La tourbe littorale du Croisic (LoireInférieure) et les dépôts analogues de l'Ouest de la France. Bulletin de la Société Scientifique et Naturelle de l'Ouest de la France 3:201-221

Welsch J (1917) Les lignites du littoral et les forêts submergées de l'Ouest de la France. Anthropologie 38:201-234

Ydier V, De Maisonneuve B (2012) Compte-rendu de découverte de bien culturel maritime: août 2012 Pêcherie de l'Acheneau, l'Épine, Vendée. Rapport du Cercle de Recherche sur l'Histoire et le Patrimoine de la Vendée, St-Gilles-Croix-de-Vie

Open Access This chapter is licensed under the terms of the Creative Commons Attribution 4.0 International License (http://creativecommons.org/licenses/by/4.0/), which permits use, sharing, adaptation, distribution and reproduction in any medium or format, as long as you give appropriate credit to the original author(s) and the source, provide a link to the Creative Commons licence and indicate if changes were made.

The images or other third party material in this chapter are included in the chapter's Creative Commons licence, unless indicated otherwise in a credit line to the material. If material is not included in the chapter's Creative Commons licence and your intended use is not permitted by statutory regulation or exceeds the permitted use, you will need to obtain permission directly from the copyright holder. 